\title{
Atmospheric input and concentration of dissolved iron in the surface layer of the Gulf of California
}

\section{Aporte atmosférico y concentración de hierro disuelto en la capa superficial del Golfo de California}

\author{
JA Segovia-Zavala ${ }^{1 *}$, F Delgadillo-Hinojosa ${ }^{1}$, ML Lares-Reyes ${ }^{2}$, \\ MA Huerta-Díaz ${ }^{1}$, A Muñoz-Barbosa ${ }^{1}$, EV Torres-Delgado ${ }^{1}$ \\ ${ }^{1}$ Instituto de Investigaciones Oceanológicas, Universidad Autónoma de Baja California, Km 103 Carretera Tijuana-Ensenada, \\ Ensenada, Baja California, México.*E-mail: jsegovia@uabc.mx \\ ${ }^{2}$ Departamento de Oceanografía Biológica, Centro de Investigación Científica y de Educación Superior de Ensenada, Km 107 \\ Carretera Tijuana-Ensenada, Ensenada, Baja California, México.
}

\section{Resumen}

Se realizó un estudio en la región central del Golfo de California (GC) para conocer los aportes de hierro atmosférico particulado $\left(\mathrm{Fe}_{\mathrm{p}}\right)$ y los factores físicos, químicos y biológicos que afectan la concentración y distribución de hierro disuelto $\left(\mathrm{Fe}_{\mathrm{d}}\right)$ en los $200 \mathrm{~m}$ superficiales del golfo. Los flujos atmosféricos de $\mathrm{Fe}_{\mathrm{p}}\left(7.0\right.$ a $\left.90.4 \mu \mathrm{mol} \mathrm{m}^{-2} \mathrm{~d}^{-1}\right)$ fueron del mismo orden de magnitud que los reportados para el Mar Rojo $\left(1.5 \mathrm{a} 116 \mu \mathrm{mol} \mathrm{m}^{-2} \mathrm{~d}^{-1}\right)$ y el Océano Pacífico nororiental $\left(24 \mu \mathrm{mol} \mathrm{m}^{-2} \mathrm{~d}^{-1}\right)$ y más altos que los registrados para el Mar Mediterráneo noroccidental $\left(0.25-0.49 \mu \mathrm{mol} \mathrm{m}^{-2} \mathrm{~d}^{-1}\right)$. En la capa superficial del GC se identifican tres regiones características: la norteña, de alta concentración, muestra un enriquecimiento superficial (5.57-7.21 $\mathrm{nM}$ ) por el predominio del aporte atmosférico; la central, con la más baja concentración, presenta un efecto de la mezcla vertical que diluye las concentraciones superficiales de $\mathrm{Fe}_{\mathrm{d}}(0.07-0.59 \mathrm{nM}) ; \mathrm{y}$ la región sur presenta una zona de concentraciones intermedias-bajas $(<1 \mathrm{nM})$ producto del predominio de la captación biológica. Se presentan dos tipos de perfiles verticales: (1) los típicos de la región sureña con menor concentración en la superficie, y un subsecuente incremento con la profundidad producto de la remineralización de la materia orgánica y (2) los perfiles mixtos de la región norte, enriquecidos en la superficie, que disminuyen a nivel subsuperficial y aumentan con la profundidad. Estos perfiles norteños están enriquecidos (hasta 23.5 veces) en relación con el Pacífico Nororiental adyacente. Los resultados de este estudio indican que la distribución de $\mathrm{Fe}_{\mathrm{d}}$ en la capa superficial del Golfo de California es gobernada por un complicado balance entre el aporte atmosférico superficial, la captación biológica, la remoción-remineralización de partículas in situ, el transporte y la mezcla.

Palabras clave: metales, hierro, aporte atmosférico, Golfo de California.

\begin{abstract}
A survey was conducted to determine the atmospheric input of particulate iron $\left(\mathrm{Fe}_{\mathrm{p}}\right)$ and the factors and processes controlling the concentration and distribution of dissolved iron $\left(\mathrm{Fe}_{\mathrm{d}}\right)$ in surface water $(200 \mathrm{~m})$ of the central Gulf of California. Atmospheric fluxes of $\mathrm{Fe}_{\mathrm{p}}\left(7.0-90.4 \mu \mathrm{mol} \mathrm{m} \mathrm{m}^{-2} \mathrm{~d}^{-1}\right)$ were of the same order of magnitude as those reported for the Red Sea $\left(1.5-116 \mu \mathrm{mol} \mathrm{m}^{-2} \mathrm{~d}^{-1}\right)$ and the northeastern Pacific Ocean $\left(24 \mu \mathrm{mol} \mathrm{m}^{-2} \mathrm{~d}^{-1}\right)$, but higher than the fluxes registered for the northwestern Mediterranean Sea $\left(0.25-0.49 \mu \mathrm{mol} \mathrm{m}^{-2} \mathrm{~d}^{-1}\right)$. According to the $\mathrm{Fe}_{\mathrm{d}}$ concentration in surface water, three different zones were identified in the study area: a northern zone with $\mathrm{Fe}_{\mathrm{d}}$ surface enrichment $(5.57-7.21 \mathrm{nM})$ due to atmospheric input, a central zone with dilution of the $\mathrm{Fe}_{\mathrm{d}}$-enriched surface water by enhanced vertical mixing $(0.07-0.59 \mathrm{nM})$, and a southern zone showing low $\mathrm{Fe}_{\mathrm{d}}$ concentrations $(<1 \mathrm{nM})$ due to biological uptake. Two types of vertical profiles were observed: (1) the typical nutrient-like distribution (with low concentrations at the surface and subsequent increase with depth) in the southern zone, and (2) mixed distribution (surface enrichment, decrease at subsurface level, and increase with depth) in the northern zone. The northern profile was 23.5 times more enriched than the adjacent Northeastern Pacific. Results indicate that $\mathrm{Fe}_{\mathrm{d}}$ distribution in the surface layer of the central Gulf of California is controlled by complex interactions involving atmospheric input, biological uptake, and in situ removal-remineralization of particles, coupled with physical transport and vertical mixing.
\end{abstract}

Key words: atmospheric input, Gulf of California, iron, metals.

\section{Introduction}

Recent oceanographic studies have shown that surface waters in the Gulf of California (GC) are enriched in trace metals $(\mathrm{Cd}, \mathrm{Ni}$, and $\mathrm{Mn})$ relative to surface waters in the adjacent Pacific Ocean (Delgadillo-Hinojosa 2000, DíazRodríguez 2008, Domínguez-Rosas 2008). Considering that

\section{Introducción}

Estudios oceanográficos recientes han demostrado que las aguas superficiales del Golfo de California (GC) están enriquecidas con metales traza ( $\mathrm{Cd}, \mathrm{Ni}$ y $\mathrm{Mn})$ en relación a las aguas superficiales del Océano Pacifico adyacente (DelgadilloHinojosa 2000, Díaz-Rodríguez 2008, Domínguez-Rosas 
the coastal population and industrial installations around the gulf are incipient, this metal enrichment cannot be attributed to anthropogenic sources; hence, natural sources and processes must be responsible for the trace-metal-enriched surface waters in the region. In the case of iron ( $\mathrm{Fe})$, the fourth most abundant element in the Earth's crust, atmospheric transport is one of its main modes of input from the continent to the sea (Turner et al. 2001). As the GC is surrounded by desert, atmospheric $\mathrm{Fe}$ inputs to surface waters should be of importance.

Knowledge is lacking of the processes affecting the distribution of $\mathrm{Fe}$ in the GC, an element that limits organic primary production (Martin 1992, Coale et al. 1996, Turner et al. 2001). The GC offers unique characteristics for the biogeochemical study of trace elements and, in particular, Fe. It is a marginal sea, considered to be one of the most productive in the world (Álvarez-Borrego and Lara-Lara 1991), surrounded by an arid continental region (Bray and Robles 1991). Winds blow along the gulf throughout the year transporting particulate material of continental origin (Douglas et al. 1993), so atmospheric transport can be considered a potentially important source of Fe input to the GC. Vertical biogenic particle flux is high from late autumn to spring, when the winds blow from the northwest and the water column is well mixed. In contrast, lithogenic or terrigenous particle flux is high in summer, when biogenic flux is low and coincides with weak southerly winds and a stratified water column (Thunell 1998). Based on the above, it can be hypothesized that wind flow and deposition is an important source of particulate $\mathrm{Fe}\left(\mathrm{Fe}_{\mathrm{p}}\right)$ of continental origin to the $\mathrm{GC}$ because it is surrounded by desert and presents a predominant wind circulation pattern along the gulf, resulting in high concentrations of dissolved $\mathrm{Fe}\left(\mathrm{Fe}_{\mathrm{d}}\right)$ in the surface layer of the GC. Atmospheric input would thus impact the surface distribution of $\mathrm{Fe}_{\mathrm{d}}$, which would be perceived as typical surface enrichment. One would also expect the GC to be $\mathrm{Fe}_{\mathrm{d}}$-enriched in relation to the adjacent Pacific Ocean.

In this paper, we present unpublished data on $\mathrm{Fe}_{\mathrm{p}}$ input and and $\mathrm{Fe}_{\mathrm{d}}$ concentrations in the surface layer obtained at a series of stations located in one of the most productive regions of the GC. The implications of our findings on the biogeochemistry of $\mathrm{Fe}$ in this region are also discussed.

\section{Material and methods}

A year-long survey was conducted from September 1997 to September 1998. Samples of atmospheric particles were collected to estimate the deposition of metals associated with particles of continental origin (Delgadillo-Hinojosa et al. 2006). Moreover, an oceanographic cruise was conducted in spring 2003 during which samples were collected from the upper $200 \mathrm{~m}$ of the water column. For the purposes of this study, samples collected between 10 and $20 \mathrm{~m}$ depth are considered superficial.
2008). Esto no puede ser atribuido a fuentes antropogénicas ya que la población costera y el desarrollo industrial que rodean al GC son incipientes. Por lo tanto, los aportes potenciales que enriquecen con metales traza las aguas superficiales del GC se deben a fuentes y a procesos naturales. En particular el hierro $(\mathrm{Fe})$, que es el cuarto elemento más abundante de la corteza terrestre, sigue la vía atmosférica como una de sus principales rutas de aporte del continente hacia el mar (Turner et al. 2001). En el caso del GC es de esperarse que el aporte atmosférico de $\mathrm{Fe}$ a las aguas superficiales sea importante ya que se encuentra rodeado de una zona desértica.

Actualmente se desconoce la distribución del Fe en el GC y los procesos que la afectan, siendo éste un elemento limitante para la producción orgánica primaria (Martin 1992, Coale et al. 1996, Turner et al. 2001). El GC ofrece características únicas para el estudio de la biogeoquímica de los elementos traza y, en particular del Fe, ya que se trata de un mar marginal considerado de los más productivos del mundo (Álvarez-Borrego y Lara-Lara 1991) y que está rodeado por una región continental árida (Bray y Robles 1991). Los vientos fluyen a lo largo del golfo durante todo el año aportándole material particulado de origen continental (Douglas et al. 1993), por lo que el transporte atmosférico se podría considerar como una ruta de aporte de Fe potencialmente importante al GC. Los flujos biogénicos verticales son altos del otoño tardío a la primavera, cuando los vientos provienen del NW y la columna de agua está bien mezclada. En contraste, el verano es un periodo de alto flujo litogénico o terrígeno (Thunell 1998); en esta época los flujos biogénicos son bajos y coinciden con una columna de agua estratificada y vientos débiles provenientes del sur (Thunell 1998). Con base en todo lo anterior, se puede hipotetizar que para el GC el flujo y depósito eólico es una fuente importante de $\mathrm{Fe}$ particulado $\left(\mathrm{Fe}_{\mathrm{p}}\right)$ de origen continental por estar rodeado de una zona continental árida y presentar un patrón de circulación de vientos predominantemente longitudinal, a lo largo del golfo. Esto producirá altas concentraciones de $\mathrm{Fe}$ disuelto $\left(\mathrm{Fe}_{\mathrm{d}}\right)$ en la capa superficial del GC. Entonces, la entrada atmosférica impactaría la distribución superficial de $\mathrm{Fe}_{\mathrm{d}}$, lo cual sería percibido como un típico enriquecimiento superficial. Adicionalmente, cabría esperar que el GC estuviera enriquecido con $\mathrm{Fe}_{\mathrm{d}}$ con relación al Océano Pacífico adyacente.

En esta investigación se reportan datos inéditos sobre el aporte de $\mathrm{Fe}_{\mathrm{p}}$ y sobre las concentraciones de $\mathrm{Fe}_{\mathrm{d}}$ en la capa superficial, obtenidos a través de una serie de estaciones localizadas en una de las regiones más productivas del GC. Adicionalmente se discuten las implicaciones de estos resultados sobre la biogeoquímica del Fe en esta región.

\section{Materiales y métodos}

Se realizó un muestreo de un año de duración de septiembre de 1997 a septiembre de 1998, en el que se recolectaron muestras de partículas atmosféricas para estimar la depositación de metales asociados a las partículas de origen continental (Delgadillo-Hinojosa et al. 2006). Además, se realizó un 


\section{Collection of atmospheric particles}

Atmospheric particles were collected in the coastal area of the Sonoran Desert, bordering the GC (fig. 1). The sampling site (Kino Bay) located in the central GC was chosen because it is relatively isolated from pollution sources. Collection began on 20 September 1997 and ended on 2 September 1998. A total of 11 samples were collected, with 16 to 45 days between samplings (Delgadillo-Hinojosa et al. 2006). During each collection, the filters were carefully removed from the collector using plastic gloves and Teflon tweezers and placed in clean, plastic Petri dishes, which were wrapped in plastic bags until analysis in the laboratory. Though the data reported in this study correspond to a single locality, the atmospheric $\mathrm{Fe}_{\mathrm{p}}$ fluxes represent a first attempt to illustrate $\mathrm{Fe}_{\mathrm{p}}$ inputs to the GC.

\section{Collection of water samples}

An oceanographic cruise was conducted in the GC during spring 2003 (12-17 May) aboard the R/V Francisco de Ulloa. The hydrographic sampling design included 38 stations distributed along three transects. For the Fe samples, only the main

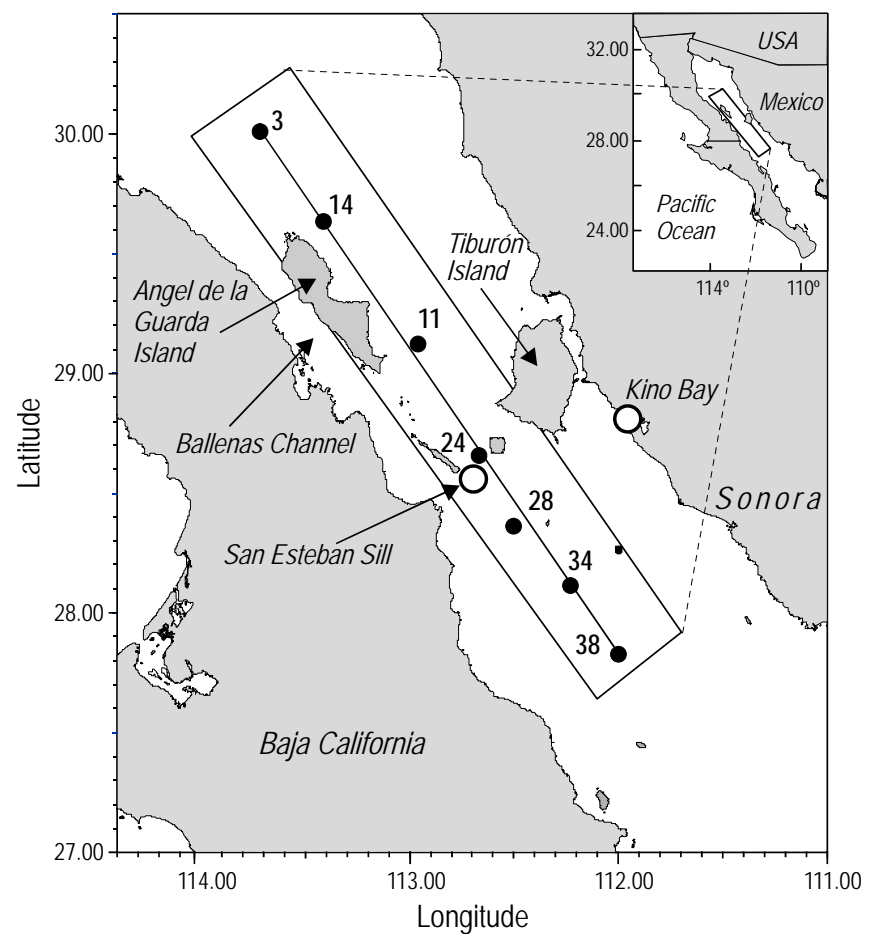

Figure 1 Location of the study area and sampling stations in the Gulf of California. The numbers indicate the hydrographic stations along the central transect (line) where the water and metal samples were collected. Atmospheric particles were collected at Kino Bay, Sonora (*).

Figura 1 Localización del área de estudio y las estaciones de muestreo en el Golfo de California. Los números indican las estaciones hidrográficas en el transecto central (línea) donde se recolectaron las muestras de agua y metales. Las partículas atmosféricas se recolectaron en Bahía Kino, Sonora $\left(^{*}\right)$. crucero oceanográfico durante la primavera de 2003, durante el cual se recolectaron muestras de agua de mar en los $200 \mathrm{~m}$ superiores de la columna de agua. Para los propósitos del presente trabajo, las muestras recolectadas entre 10 y $20 \mathrm{~m}$ fueron consideradas como superficiales.

\section{Recolección de partículas atmosféricas}

La recolección de partículas atmosféricas se realizó en la zona costera del desierto de Sonora, aledaña al GC (fig. 1). El sitio de muestreo (Bahía Kino) fue seleccionado en la región central del GC, debido a que se encuentra relativamente aislado de fuentes de contaminación. La recolección se inició el 20 de septiembre de 1997 y terminó el 2 de septiembre de 1998. En total se recolectaron 11 muestras, con periodos entre muestreos que variaron entre 16 y 45 días (Delgadillo-Hinojosa et al. 2006). En cada recolecta, los filtros se retiraron cuidadosamente del colector utilizando guantes de plástico y pinzas de Teflón; y posteriormente se colocaron en cajas de Petri plásticas limpias, las cuales se envolvieron en bolsas de plástico hasta su análisis posterior en el laboratorio. Aunque los datos reportados en este trabajo provienen de una sola localidad, los flujos eólicos de $\mathrm{Fe}_{\mathrm{p}}$ representan un primer intento ilustrativo de cuantificar tales flujos al GC.

\section{Recolección de muestras de agua}

Se realizó un crucero oceanográfico en el GC durante la primavera de 2003 (12-17 de mayo) a bordo del B/O Francisco de Ulloa. El diseño hidrográfico del muestreo incluyó un total de 38 estaciones distribuidas en tres transectos. Para las muestras de Fe solamente se consideró el transecto principal situado a lo largo del eje central y entre las islas del GC (estaciones 3, 14, 11, 24, 28, 34 y 38; fig. 1). El área de estudio se dividió en dos zonas de acuerdo a su posición geográfica respecto al norte y sur del Umbral de San Esteban (fig. 1): zona norte con las estaciones 3, 14 y 11 y la zona centro-sur con las estaciones $24,28,34$ y 38 .

Los perfiles de temperatura, salinidad, oxígeno disuelto $\left(\mathrm{O}_{2}\right)$ y clorofilas (Chla) se obtuvieron con un CTD marca SeaBird. El procedimiento de recolecta y procesado de las muestras de Fe se llevó a cabo mediante técnicas de "ultra limpieza" (Bruland et al. 1979). Se instaló en el barco un laboratorio (cuarto limpio) prefabricado hecho de plástico (área $\sim 6 \mathrm{~m}^{2}$ ) y equipado con una campana de flujo laminar portátil (Environment Class 100) para crear una atmósfera positiva y un ambiente libre de polvo (Segovia-Zavala et al. 1998). La recolección de muestras se realizó por medio de botellas Go-Flo de $5 \mathrm{~L}$, recubiertas de Teflón y montadas en una roseta. La roseta fue previamente tratada con pintura epóxica y recubierta con cinta adhesiva de plástico. Para minimizar la contaminación de los ánodos de sacrificio de zinc y de la roseta, la toma de la muestra $\left(\mathrm{Fe}_{\mathrm{d}}\right)$ se realizó disparando las botellas GoFlo cuando la roseta ascendía a una velocidad de $5 \mathrm{~m} \mathrm{~min}^{-1}$ 
transect was considered, situated along the gulf's central axis and between the islands (stations 3, 14, 11, 24, 28, 34, and 38; fig. 1). The study area was divided into two zones depending on their geographic position relative to the north and south of San Esteban Sill (fig. 1): northern zone, comprising stations 3, 14 , and 11; and central-southern zone, comprising stations 24 , 28,34 , and 38 .

Temperature, salinity, dissolved oxygen $\left(\mathrm{O}_{2}\right)$, and chlorophyll (Chla) profiles were obtained using a SeaBird CTD. Ultra-clean techniques were applied for the collection and processing of the Fe samples (Bruland et al. 1979). A prefabricated, plastic laboratory (clean room, $\sim 6 \mathrm{~m}^{2}$ in area) was installed on board and equipped with a portable laminar flow hood (Environment Class 100) to create a positive, dust-free environment (Segovia-Zavala et al. 1998). Water samples were collected in 5-L Teflon-lined Go-Flo bottles mounted on a rosette. The rosette was previously treated with epoxy paint and covered with plastic adhesive tape. To minimize contamination of the $\mathrm{Zn}$ nodes and rosette, samples $\left(\mathrm{Fe}_{\mathrm{d}}\right)$ were collected by casting the Go-Flo bottles when the rosette was rising at a speed of $5 \mathrm{~m} \mathrm{~min}^{-1}$ (Cullen and Sherrell 1999). Water samples were collected at 10,20,50,75, 100, and $200 \mathrm{~m}$ depth.

\section{Analysis of $\mathrm{Fe}_{\mathrm{d}}$}

For the determination of $\mathrm{Fe}_{\mathrm{d}}$, water from the Go-Flo bottles was filtered in the clean room. From 1 to $5 \mathrm{~L}$ of seawater were passed through polycarbonate membrane filters $(0.45-\mu \mathrm{m}$ pore size, $47 \mathrm{~mm}$ diameter), using an on-line filtration system consisting of Teflon tubing and a peristaltic pump (DelgadilloHinojosa et al. 2001). The membrane filters were previously acid washed, rinsed with deionized water, dried, and weighed (Cullen and Sherrel 1999). The dissolved phase was defined as all the material passing through a $0.45-\mu \mathrm{m}$ filter. The samples were placed in 1-L low-density polyethylene (LDPE) bottles, which had been previously rinsed five times with the sample, then filled and acidified at $\mathrm{pH}<2$, adding $1 \mathrm{~mL}$ of $\mathrm{HNO}_{3}$ (Ultrex) per liter of seawater. Finally, the samples were stored in double plastic bags, within a plastic bucket, until analysis in the laboratory.

\section{Measurement of Fe in dissolved phase and in atmospheric particles}

Analysis of $\mathrm{Fe}_{\mathrm{d}}$ was performed by organic extraction and preconcentration with organic chelants (APDC) in a laminar flow hood under positive atmospheric conditions (Bruland et al. 1979), and by inductively coupled plasma mass spectrometry (ICP-MS, Finnigan Element II High Performance High Resolution). The detection limit (three times the standard deviation of 10 replicates of the analytical blanks) was $0.036 \mathrm{nM}$. The precision and accuracy of the analysis was determined by analyzing nearshore seawater reference material (CASS-4). The value measured was $12.56 \pm 0.89 \mathrm{nM}$ and did
(Cullen ySherrell 1999). En general, las muestras de agua se recolectaron a $10,20,50,75,100$ y $200 \mathrm{~m}$ de profundidad.

\section{Análisis de $\mathrm{Fe}_{\mathrm{d}}$}

Para la determinación de $\mathrm{Fe}_{\mathrm{d}}$, los filtrados del agua de las botellas Go-Flo se realizaron en el cuarto limpio. Se filtraron de 1 a $5 \mathrm{~L}$ de agua de mar a través de membranas de policarbonato (poro de $0.45 \mu \mathrm{m}, 47 \mathrm{~mm}$ de diámetro), mediante un sistema de filtración "en línea" que incluyó tubería de Teflón y una bomba peristáltica (Delgadillo-Hinojosa et al. 2001). Los filtros de membrana fueron previamente lavados con ácidos, enjuagados con agua desionizada, secados y pesados (Cullen y Sherrel 1999). La fase disuelta fue definida como todo el material que pasara a través del filtro de $0.45 \mu \mathrm{m}$. Las muestras se guardaron en botellas de polietileno de baja densidad (LDPE) de $1 \mathrm{~L}$, mismas que fueron previamente enjuagadas cinco veces con la muestra, luego llenadas y acidificadas a $\mathrm{pH}<2$ adicionando $1 \mathrm{~mL}$ de $\mathrm{HNO}_{3}$ Ultrex por litro de agua de mar. Finalmente las muestras se almacenaron en doble bolsa de plástico y en el interior de una cubeta de plástico hasta su análisis posterior en el laboratorio.

\section{Medición del Fe en la fase disuelta y en partículas atmosféricas.}

El análisis del $\mathrm{Fe}_{\mathrm{d}}$ se llevó a cabo por la extracción orgánica y preconcentración con quelantes orgánicos (APDC) en una campana de flujo laminar bajo condiciones de atmósfera positiva (Bruland et al. 1979). El análisis del $\mathrm{Fe}_{\mathrm{d}}$ se realizó mediante la técnica de espectrometría de masas de alta resolución con plasma acoplado por inducción (ICP-MS; Finnigan Element II High Performance High Resolution). El límite de detección (tres veces la desviación estándar de 10 réplicas de los blancos analíticos) fue $0.036 \mathrm{nM}$. La precisión y exactitud del análisis se cuantificó analizando un estándar de referencia de agua de mar de origen costero (CASS-4). El valor medido fue $12.56 \pm 0.89 \mathrm{nM}$, el cual no mostró diferencias significativas $(95 \%)$ con el valor certificado de $12.76 \pm 1.04 \mathrm{nM}$.

El análisis del Fe en las partículas atmosféricas se llevó a cabo mediante espectrometría de absorción atómica posterior a un procedimiento de digestión de los filtros, de acuerdo a lo descrito por Landing y Lewis (1991) y Delgadillo-Hinojosa (2000). Brevemente, los filtros con las partículas se colocaron en vasos de Teflón y se digirieron con una mezcla de $\mathrm{HNO}_{3}$, $\mathrm{HClO}_{4}$ y $\mathrm{HF}$ a $250^{\circ} \mathrm{C}$ por $2 \mathrm{~h}$. Al final de la digestión el HF se neutralizó con ácido bórico. Los filtros y blancos de procedimiento fueron analizados en la misma corrida. La cuantificación del Fe en los extractos se llevó a cabo usando el modo de flama en un espectrofotómetro de absorción atómica Varian 220FS equipado con un sistema de corrección de fondo de lámpara de deuterio. La precisión y exactitud del método fueron evaluadas por el análisis de un estándar de referencia. La concentración de Fe del estándar de referencia (MESS-3, National Research Council of Canada) es de $4.34 \pm 0.11 \%$ y la medida con el procedimiento fue de $4.64 \pm 0.38 \%$. 
not show significant differences $(95 \%)$ with the certified value of $12.76 \pm 1.04 \mathrm{nM}$.

Analysis of $\mathrm{Fe}$ in atmospheric particles was performed by atomic absorption spectrometry after digestion of the filters, according to that described by Landing and Lewis (1991) and Delgadillo-Hinojosa (2000). Briefly, the filters containing the particles were placed in Teflon containers and digested with a mixture of $\mathrm{HNO}_{3}, \mathrm{HClO}_{4}$, and $\mathrm{HF}$ at $250^{\circ} \mathrm{C}$ for $2 \mathrm{~h}$, after which HF was neutralized with boric acid. The filters and procedural blanks were analyzed during the same run. The $\mathrm{Fe}$ in the extracts was quantified using a Varian 220FS flame atomic absorption spectrophotometer equipped with a deuterium lamp as background correction system. The precision and accuracy of the method was evaluated by analyzing standard reference material (MESS-3, National Research Council of Canada). The $\mathrm{Fe}$ concentration measured with this procedure was $4.64 \pm$ $0.38 \%$, compared with the reference value of $4.34 \pm 0.11 \%$.

\section{Hydrochemical variables}

In addition to $\mathrm{Fe}_{\mathrm{d}}$, samples were taken for the analysis of variables that are necessary to establish physical and biogeochemical associations with this element. Salinity was determined using a GuildLine $8400 \mathrm{~B}$ salinometer, and $\mathrm{O}_{2}$ was analyzed by the Winkler method using a microburette (Carpenter 1965). Nitrates $\left(\mathrm{NO}_{3}\right)$ were measured using a Skalar ${ }^{\text {Plus }}$ segmented flow analyzer, according to Bernhardt and Wilhelms (1967). The Chla samples were analyzed using a Turner 112 fluorometer, following the method described by Holm-Hansen et al. (1965), and the concentrations were calculated according to Parsons et al. (1984). The detection limits for the $\mathrm{NO}_{3}$ and Chla measurements were $0.05 \mu \mathrm{M}$ and $0.002 \mathrm{mg} \mathrm{m}^{-3}$, respectively.

\section{Results}

Atmospheric input of $\mathrm{Fe}_{\mathrm{p}}$

During the year of survey, the total flux of atmospheric particles oscillated between 12 and $143 \mathrm{mg} \mathrm{m}^{-2} \mathrm{~d}^{-1}$, showing seasonal variability with higher values $\left(>65 \mathrm{mg} \mathrm{m}^{-2} \mathrm{~d}^{-1}\right)$ in summer and autumn (Delgadillo-Hinojosa et al. 2006), and lower deposition values ( $\left.<40 \mathrm{mg} \mathrm{m}^{-2} \mathrm{~d}^{-1}\right)$ in spring (fig. 2). The concentrations of $\mathrm{Fe}_{\mathrm{p}}$ were relatively variable (mean $=372 \pm$ $186 \mu \mathrm{mol} \mathrm{g}^{-1}$ ), ranging from 140 to $634 \mathrm{mmol} \mathrm{g}^{-1}$ (fig. 2). These concentrations represent an atmospheric Fe flux of $7.0-90.4 \mu \mathrm{mol} \mathrm{m}^{-2} \mathrm{~d}^{-1}\left(\right.$ mean $=23.65 \pm 25.90 \mu \mathrm{mol} \mathrm{m}^{-2} \mathrm{~d}^{-1}$, $n=10$ ). The variability of atmospheric Fe flux was relatively low for most of the time (spring/autumn); however, the July value was one order of magnitude higher, contributing to the increase in total flux variability.

\section{Distribution of $\mathrm{Fe}_{\mathrm{d}}$}

Mean $\mathrm{Fe}_{\mathrm{d}}$ concentration in all the 200-m layer was $2.0 \pm$ $1.8 \mathrm{nM}(n=38)$, with minimum values of $0.07-0.21 \mathrm{nM}$ at

\section{Variables hidroquímicas}

Además del $\mathrm{Fe}_{\mathrm{d}}$ se tomaron muestras para el análisis de variables necesarias para establecer asociaciones físicas y biogeoquímicas con este elemento. La salinidad se determinó por medio de un salinómetro GuildLine 8400B. $\mathrm{El}_{2}$ se analizó por el método Winkler utilizando una microbureta (Carpenter 1965). Los nitratos $\left(\mathrm{NO}_{3}\right)$ se midieron con un analizador de flujo segmentado Skalar ${ }^{\text {Plus de }}$ acuerdo con Bernhardt y Wilhelms (1967). Las muestras de Chla se analizaron utilizando un fluorímetro Turner 112 siguiendo el método descrito por Holm-Hansen et al. (1965) y los cálculos de concentración se realizaron de acuerdo con Parsons et al. (1984). Los límites de detección de los métodos para $\mathrm{NO}_{3}$ y Chla fueron $0.05 \mu \mathrm{M} \mathrm{y}$ $0.002 \mathrm{mg} \mathrm{m}^{-3}$, respectivamente.

\section{Resultados}

\section{Aporte atmosférico de $\mathrm{Fe}_{\mathrm{p}}$}

Durante el año de muestreo, el flujo total de partículas atmosféricas varió de 12 a $143 \mathrm{mg} \mathrm{m}^{-2} \mathrm{~d}^{-1}$, mostrando una variabilidad estacional con valores mayores durante el verano y otoño ( $>65 \mathrm{mg} \mathrm{m}^{-2} \mathrm{~d}^{-1}$; Delgadillo-Hinojosa et al. 2006). En contraste, durante la primavera se presentó una menor tasa de depositación con valores $<40 \mathrm{mg} \mathrm{m}^{-2} \mathrm{~d}^{-1}$ (fig. 2). Las concentraciones de hierro particulado $\left(\mathrm{Fe}_{\mathrm{p}}\right)$ fueron relativamente variables (promedio $=372 \pm 186 \mu \mathrm{mol} \mathrm{g}^{-1}$ ), oscilando entre 140 y $634 \mu \mathrm{mol} \mathrm{g}^{-1}$ (fig. 2). Estas concentraciones representan para el periodo de muestreo un flujo atmosférico de Fe del orden de 7.0 a $90.4 \mu \mathrm{mol} \mathrm{m}{ }^{-2} \mathrm{~d}^{-1}$ (promedio $=23.65 \pm 25.90$ $\left.\mu \mathrm{mol} \mathrm{m} \mathrm{m}^{-2} \mathrm{~d}^{-1}, n=10\right)$. La variabilidad del flujo atmosférico de

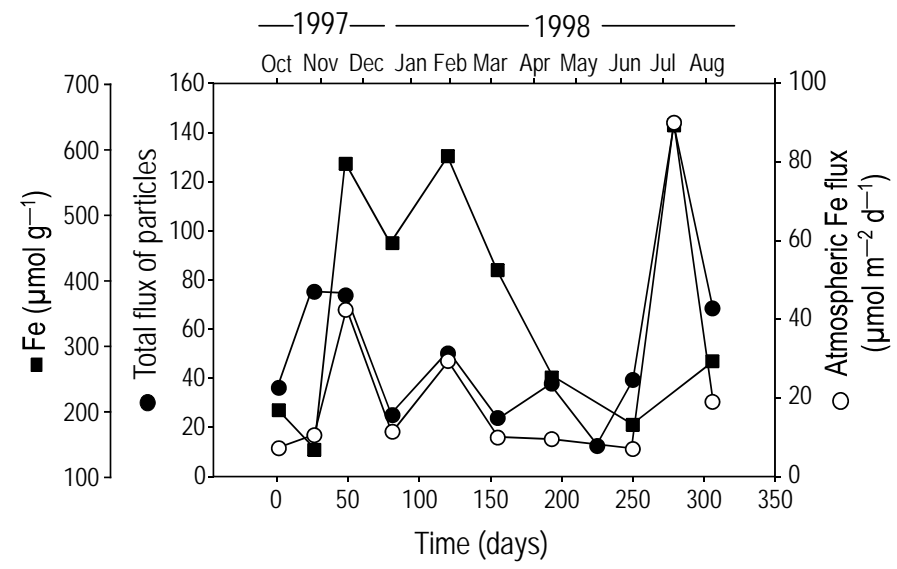

Figure 2. Time series of Fe concentration ( $\square$ ) in atmospheric particles deposited during the period from September 1997 to September 1998 in Kino Bay, Sonora. Also indicated are the total flux of atmospheric particles $(\bullet)$ and atmospheric fluxes of $\mathrm{Fe}(\mathrm{O})$ in the Gulf of California.

Figura 2. Serie de tiempo de la concentración de Fe ( $\mathbf{\square})$ en las partículas atmosféricas depositadas de septiembre 1997 a septiembre 1998 en Bahía Kino, Sonora. Adicionalmente se indican el flujo total de partículas atmosféricas (•) y los flujos atmosféricos de Fe (O) depositados en el GC. 
Table 1 Surface temperature, salinity, dissolved iron $\left(\mathrm{Fe}_{\mathrm{d}}\right)$, oxygen $\left(\mathrm{O}_{2}\right)$, chlorophll a $(\mathrm{Chla})$, and nitrate $\left(\mathrm{NO}_{3}\right)$ data for the Gulf of California in May 2003 (spring).

Tabla 1 Datos superficiales de temperatura, salinidad, hierro disuelto $\left(\mathrm{Fe}_{\mathrm{d}}\right)$, oxígeno $\left(\mathrm{O}_{2}\right)$, clorofila a $(\mathrm{Chla})$ y nitrato $\left(\mathrm{NO}_{3}\right)$ para mayo de $2003($ primavera $)$ en el Golfo de California.

\begin{tabular}{|c|c|c|c|c|c|c|c|}
\hline Station & $\begin{array}{l}\text { Depth } \\
\text { (m) }\end{array}$ & $\begin{array}{c}\text { Temperature } \\
\left({ }^{\circ} \mathrm{C}\right)\end{array}$ & Salinity & $\begin{array}{l}\mathrm{Fe}_{\mathrm{d}} \\
(\mathrm{nM})\end{array}$ & $\begin{array}{c}\mathrm{O}_{2} \\
(\mu \mathrm{M})\end{array}$ & $\begin{array}{c}\text { Chla } \\
\left(\mathrm{mg} \mathrm{m}^{3}\right)\end{array}$ & $\begin{array}{l}\mathrm{NO}_{3} \\
(\mu \mathrm{M})\end{array}$ \\
\hline \multirow[t]{5}{*}{3} & 10 & 19.61 & 35.525 & 7.21 & 299 & 2.13 & 0.41 \\
\hline & 20 & 19.10 & 35.505 & 0.20 & 274 & 2.11 & 0.41 \\
\hline & 50 & 17.06 & 35.373 & 0.65 & 188 & 0.13 & 14.4 \\
\hline & 75 & 15.69 & 35.247 & 1.05 & 135 & 0.09 & 18.9 \\
\hline & 100 & 15.19 & 35.244 & 3.62 & 94 & 0.09 & 20.0 \\
\hline \multirow[t]{6}{*}{14} & 10 & 17.08 & 35.282 & 5.57 & 213 & 0.72 & 12.5 \\
\hline & 20 & 16.51 & 35.240 & 0.88 & 185 & 0.44 & 15.0 \\
\hline & 50 & 15.97 & 35.205 & 1.53 & 165 & 0.12 & 15.3 \\
\hline & 75 & 15.65 & 35.187 & 2.21 & 151 & 0.05 & 17.7 \\
\hline & 100 & 15.26 & 35.165 & 4.50 & 136 & 0.04 & 18.4 \\
\hline & 200 & 13.50 & 35.029 & 4.61 & 95 & 0.02 & 23.6 \\
\hline \multirow[t]{6}{*}{11} & 10 & 20.04 & 35.468 & 6.42 & 263 & 1.70 & 2.9 \\
\hline & 20 & 19.23 & 35.422 & 2.77 & 276 & 1.30 & 10.0 \\
\hline & 50 & 16.71 & 35.307 & 1.61 & 200 & 0.33 & 17.2 \\
\hline & 75 & 15.91 & 35.243 & 2.98 & 167 & 0.13 & 18.9 \\
\hline & 100 & 15.31 & 35.187 & 2.35 & 146 & 0.07 & 20.0 \\
\hline & 200 & 12.82 & 34.980 & 2.77 & 81 & 0.05 & 23.2 \\
\hline \multirow[t]{5}{*}{24} & 20 & 15.03 & 35.169 & 0.59 & 126 & 0.20 & 12.5 \\
\hline & 50 & 14.19 & 35.102 & 0.21 & 105 & 0.04 & 18.4 \\
\hline & 75 & 13.84 & 35.071 & 0.68 & 102 & 0.04 & 19.2 \\
\hline & 100 & 13.42 & 35.033 & 0.07 & 96 & 0.02 & 20.6 \\
\hline & 200 & 11.51 & 34.861 & 1.31 & 63 & 0.02 & 21.2 \\
\hline \multirow[t]{6}{*}{28} & 10 & 18.30 & 35.237 & 0.13 & 214 & 0.93 & 7.14 \\
\hline & 20 & 17.30 & 35.222 & 0.10 & 184 & 0.98 & 9.5 \\
\hline & 50 & 15.80 & 35.147 & 0.19 & 144 & 0.52 & 13.1 \\
\hline & 75 & 14.89 & 35.100 & 1.01 & 122 & 0.25 & 15.6 \\
\hline & 100 & 14.60 & 35.092 & 1.04 & 116 & 0.23 & 19.9 \\
\hline & 200 & 12.30 & 34.904 & 1.30 & 68 & 0.05 & 22.0 \\
\hline \multirow[t]{4}{*}{34} & 20 & 17.10 & 35.176 & 0.78 & 178 & 1.19 & 4.8 \\
\hline & 50 & 14.58 & 35.049 & 0.45 & 100 & 0.07 & 14.9 \\
\hline & 75 & 14.12 & 35.046 & 2.55 & 105 & 0.04 & 18.6 \\
\hline & 100 & 13.83 & 35.024 & 2.53 & 98 & 0.03 & 19.4 \\
\hline \multirow[t]{6}{*}{38} & 10 & 22.55 & 35.521 & 1.32 & 240 & 0.37 & 0.12 \\
\hline & 20 & 22.25 & 35.507 & 1.47 & 241 & 1.19 & 0.08 \\
\hline & 50 & 17.95 & 35.212 & 1.93 & 161 & 0.04 & 19.7 \\
\hline & 75 & 15.42 & 35.094 & 2.19 & 103 & 0.03 & 19.8 \\
\hline & 100 & 14.52 & 35.026 & 2.66 & 90 & 0.03 & 20.2 \\
\hline & 200 & 12.92 & 34.883 & 2.73 & 45 & 0.02 & 22.6 \\
\hline
\end{tabular}


station 24 and $0.10-0.19 \mathrm{nM}$ at station 28 (table 1). Maximum concentrations were 5.57, 6.42, and $7.21 \mathrm{nM}$ in surface samples $(10-20 \mathrm{~m})$ from stations 14,11 , and 3 respectively (table 1). The $\mathrm{Fe}_{\mathrm{d}}$ concentrations in the most superficial samples from the northern zone (stations 14, 11, and 3) were higher (approximate ratio of $9: 1$ ) than in those from the centralsouthern zone (stations 24, 28, 34, and 38) of the study area (fig. 3).

The vertical distribution of $\mathrm{Fe}_{\mathrm{d}}$ along the transect showed two main characteristics: in the northern zone, high surface $\mathrm{Fe}_{\mathrm{d}}$ values $(4 \mathrm{nM})$ were recorded in a southward-projecting tongue (10-100 m) between stations 3 and 11 (fig. 4); and in the central-southern zone, low $\mathrm{Fe}_{\mathrm{d}}$ concentraciones $(0.5-1.0 \mathrm{nM})$ were found between stations 24 and 38. Moreover, vertical isolines of $\mathrm{Fe}_{\mathrm{d}}$ were observed between stations 11 and 24 (1 and $2 \mathrm{nM})$. In general, mean vertical distribution of $\mathrm{Fe}_{\mathrm{d}}$ in the northern zone showed high values at the surface $(6.4 \mathrm{nM})$, decreasing at intermediate depths $(1.3 \mathrm{nM})$, and increasing again at $200 \mathrm{~m}$ depth (4.32 nM; fig. 5a), whereas in the centralsouthern zone, the values were low $(0.73 \mathrm{nM})$ at the surface and increased with depth (2.0 nM; fig. 5b). Mean vertical distribution (fig. 6) also showed $\mathrm{Fe}_{\mathrm{d}}$-enriched surface waters relative to the adjacent Pacific Ocean (Landing and Bruland 1987); this enrichment is more evident in the northern part of our transect.

\section{Discussion}

\section{Atmospheric Fe input}

The GC is a semi-closed sea, strongly influenced by the surrounding arid lands (Bray and Robles 1991) and by the winds that flow along the gulf throughout the year (Douglas et al. 1993) transporting particulate material of continental origen. Hence, atmospheric dust transport plays an important role in $\mathrm{Fe}_{\mathrm{p}}$ input to the sea. The high seasonal variability of total atmospheric particle flux (12-143 $\left.\mathrm{mg} \mathrm{m}^{-2} \mathrm{~d}^{-1}\right)$, with higher values in summer and autumn $\left(>65 \mathrm{mg} \mathrm{m}^{-2} \mathrm{~d}^{-1}\right)$ and lower in spring $\left(<40 \mathrm{mg} \mathrm{m}^{-2} \mathrm{~d}^{-1}\right)$, indicates greater particle flux during summer and autumn (fig. 2; Delgadillo-Hinojosa et al. 2006). In a study using sediment traps, Thunell (1998) also found that total input to the sediment in the central GC tends to be dominated by terrigenous material in summer and early autumn. Baumgartner et al. (1991) reported that a large part of the terrigenous input to the GC is due to wind transport associated with the storms that occur in the Sonoran Desert in summer. Delgadillo-Hinojosa (2000) estimated total atmospheric particle flux to the GC using data from a station in Sonora and suggested that at least $43 \%$ of the wind inputs contributed to the flux of terrigenous material estimated by Thunell (1998). In this study, atmospheric particles were only collected at one station, which is not enough to reflect the seasonality of particle flow to the GC. It is therefore important to conduct intensive studies using a reasonable number of stations strategically located on the coasts of both Baja California and Sonora, as
Fe fue relativamente baja durante la mayor parte del tiempo (primavera-otoño); sin embargo, el valor de julio fue un orden de magnitud más alto, lo que contribuyó al aumento en la variabilidad total del flujo.

\section{Distribución de $F e_{\mathrm{d}}$}

La concentración media de $\mathrm{Fe}_{\mathrm{d}}$ en toda la capa de $200 \mathrm{~m}$ fue de $2.0 \pm 1.8 \mathrm{nM}(n=38)$ con valores mínimos entre 0.07 y 0.21 $\mathrm{nM}$ en la estación 24 , y entre 0.10 y $0.19 \mathrm{nM}$ en la estación 28 (tabla 1). Las concentraciones máximas fueron de 5.57, 6.42 y $7.21 \mathrm{nM}$ en las muestras superficiales $(10-20 \mathrm{~m})$ de las estaciones 14,11 y 3 , respectivamente (tabla 1 ). Las concentraciones de $\mathrm{Fe}_{\mathrm{d}}$ en las muestras más superficiales de la zona norte (estaciones 14,11 y 3 ) son mayores, en una proporción aproximada de 9:1 en comparación con la zona centro-sur (estaciones 24, 28, 34 y 38) del área de estudio (fig. 3).

La distribución vertical de $\mathrm{Fe}_{\mathrm{d}}$ a lo largo del transecto mostró dos características principales. En la parte norte, de la estación 3 a la 11 se presentaron altos valores superficiales de $\mathrm{Fe}_{\mathrm{d}}$ $(4 \mathrm{nM})$ en una lengüeta (entre 10 y $100 \mathrm{~m}$ ) que se proyecta hacia el sur (fig. 4). La otra característica que se observa es en la parte sur, en donde se presenta una distribución de $\mathrm{Fe}_{\mathrm{d}}$ con concentraciones bajas entre las estaciones 24 y 38 (0.5-1.0 $\mathrm{nM})$. Asimismo, entre las estaciones 11 y 24 se observan isolíneas verticales de $\mathrm{Fe}_{\mathrm{d}}(1$ y $2 \mathrm{nM})$. En general, la distribución vertical media de la región norte presenta altos valores de $\mathrm{Fe}_{\mathrm{d}}$ superficiales $(6.4 \mathrm{nM})$, que diminuyen en profundidades intermedias (1.3 nM), y finalmente se incrementan hasta los $200 \mathrm{~m}$ (4.32 nM; fig. 5a). En contraste, la distribución vertical media de la región central y sureña presenta valores bajos $(0.73 \mathrm{nM})$ en la superficie, que aumentan con la profundidad $(2.0 \mathrm{nM}$; fig. $5 b)$. También se puede apreciar en la distribución vertical media (fig. 6) el enriquecimiento superficial de $\mathrm{Fe}_{\mathrm{d}}$ con relación al Océano Pacifico adyacente (Landing y Bruland, 1987), el cual es más evidente en la región norteña de nuestro transecto.

\section{Discusión}

\section{Aporte atmosférico de Fe}

El GC es un mar semicerrado que se encuentra bajo una fuerte influencia de las tierras áridas circundantes (Bray y Robles 1991) y de los vientos que fluyen a lo largo del GC durante todo el año (Douglas et al. 1993) aportando en el proceso material particulado de origen continental. Por lo tanto, el transporte de polvo atmosférico constituye una ruta muy importante de aporte de $\mathrm{Fe}_{\mathrm{p}}$ hacia el mar. Entonces, la gran variabilidad estacional del flujo atmosférico de partículas totales (12 a $\left.143 \mathrm{mg} \mathrm{m}^{-2} \mathrm{~d}^{-1}\right)$, con valores mayores durante la temporada de verano y otoño ( $\left.>65 \mathrm{mg} \mathrm{m}^{-2} \mathrm{~d}^{-1}\right)$ y menores durante la primavera $\left(<40 \mathrm{mg} \mathrm{m}^{-2} \mathrm{~d}^{-1}\right)$, da como resultado un mayor flujo de partículas durante verano-otoño (fig. 2; DelgadilloHinojosa et al. 2006). Este resultado es congruente con el 
Stations

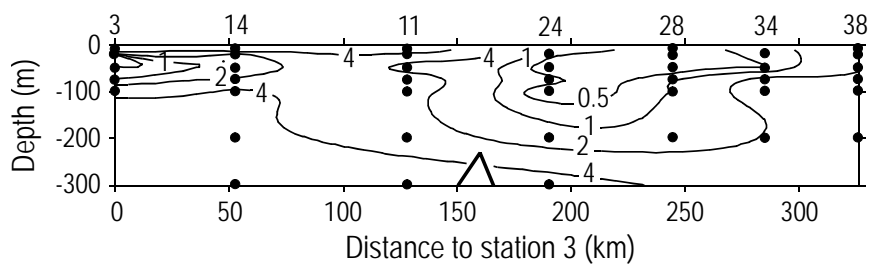

Figure 3. Vertical distribution of $\mathrm{Fe}_{\mathrm{d}}(\mathrm{nM})$ at the sampling stations along the transect parallel to the main axis of the Gulf of California (see fig. 1). The triangle at $150 \mathrm{~km}$ refers to the upper part of San Esteban Sill.

Figura 3. Distribución vertical de $\mathrm{Fe}_{\mathrm{d}}(\mathrm{nM})$ en el transecto paralelo al eje central del Golfo de California (ver fig. 1). El triángulo inferior a $150 \mathrm{~km}$ es la parte superior del Umbral de San Esteban.

well as between the islands, to establish with greater certainty the spatial and temporal variability of the input of atmospheric particles to the GC.

Atmospheric fluxes of $\mathrm{Fe}_{\mathrm{p}}\left(7.0-90.4 \mu \mathrm{mol} \mathrm{m}^{-2} \mathrm{~d}^{-1}\right)$ were of the same order of magnitude as those reported for the Red Sea (1.5-116 $\mu \mathrm{mol} \mathrm{m}^{-2} \mathrm{~d}^{-1}$, Chase et al. 2006), the northeastern Pacific Ocean ( $24 \mu \mathrm{mol} \mathrm{m}^{-2} \mathrm{~d}^{-1}$, Johnson et al. 2003), and the western Mediterranean Sea $\left(39.98 \pm 3.80 \mu \mathrm{mol} \mathrm{m} \mathrm{m}^{-2} \mathrm{~d}^{-1}\right.$, Sarthou and Jeandel 2001; 10.70-54.6 $\mu \mathrm{mol} \mathrm{m}^{-2} \mathrm{~d}^{-1}$, Bonnet and Guieu 2006), but higher than those reported for the northwestern Mediterranean Sea $\left(0.25-0.49 \mu \mathrm{mol} \mathrm{m}^{-2} \mathrm{~d}^{-1}\right.$, Guieu et al. 1997). Our data thus suggest that atmospheric $\mathrm{Fe}_{\mathrm{p}}$ input to

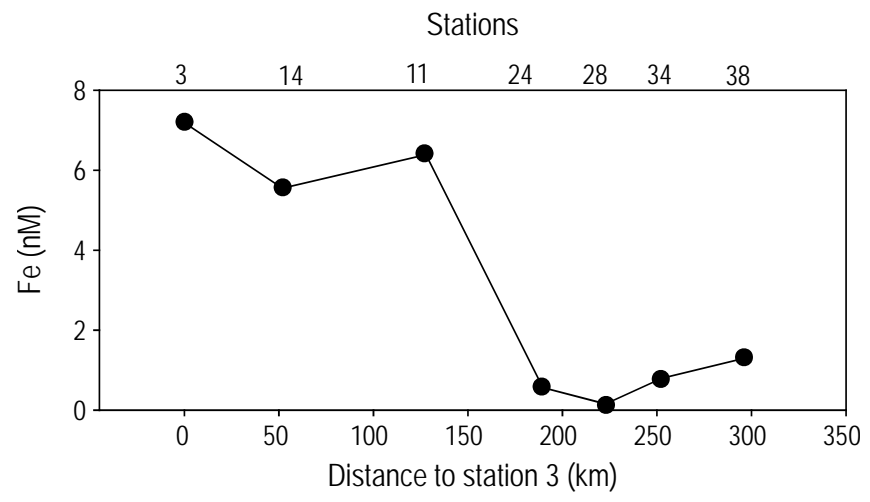

Figure 4. Horizontal distribution of surface $\mathrm{Fe}_{\mathrm{d}}$ concentration (nM) at the sampling stations along the central transect in the Gulf of California (see fig. 1).

Figura 4. Distribución horizontal de la concentración superficial de $\mathrm{Fe}_{\mathrm{d}}$ (nM) en el transecto central del Golfo de California. (ver fig. 1).

estudio realizado con trampas de sedimentos por Thunell (1998), quien reportó que los aportes totales al sedimento de la región central del GC tienden a estar dominados por material terrígeno durante el verano y el otoño temprano. Baumgartner et al. (1991) sugirieron que gran parte del aporte terrígeno al GC se debe al aporte eólico asociado a las tormentas del desierto de Sonora, las cuales ocurren durante el verano. Además, Delgadillo-Hinojosa (2000) estimó los aportes atmosféricos de partículas totales al GC con datos de una
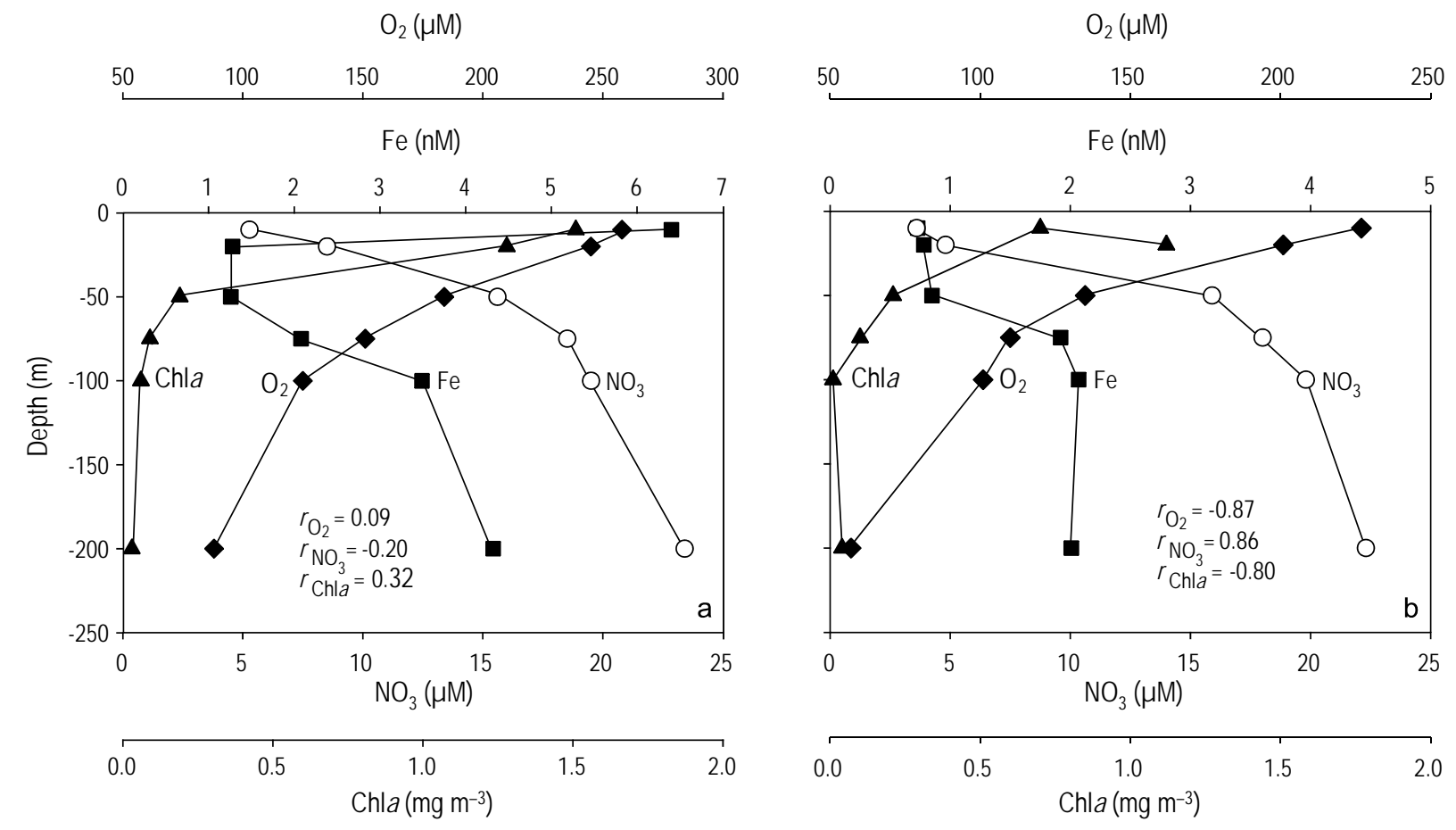

Figure 5. Mean vertical profile of $\mathrm{Fe}_{\mathrm{d}}(\mathbf{\square}), \mathrm{NO}_{3}(\mathrm{O}), \mathrm{O}_{2}(\boldsymbol{\bullet})$, and Chla $(\mathbf{\Delta})$ in (a) the northern zone (stations 3,11 , and 14) and (b) the central-southern zone (stations $24,28,34$, and 38 ) of the study area.

Figura 5. Perfil vertical medio de $\mathrm{Fe}_{\mathrm{d}}(\boldsymbol{\nabla}), \mathrm{NO}_{3}(\mathrm{O}), \mathrm{O}_{2}(\boldsymbol{\bullet})$ y Chla $(\boldsymbol{\Delta})$ en (a) la región norte (estaciones 3,11 y 14$)$ y (b) la región centralsur (estaciones 24, 28, 34 y 38) del área de estudio. 
the GC is important, depending on its solubility in seawater. Laboratory experiments have shown that $\mathrm{Fe}$ solubility varies between 1\% and 10\% (Spokes and Jickells 1996, Jickells and Spokes 2001). For the northeastern Pacific Ocean, Johnson et al. (2003) estimated that the solubility of Fe was $3.33 \%$. We can therefore assume a solubility of $3 \%$ for $\mathrm{Fe}_{\mathrm{p}}$ in the $\mathrm{GC}$, which when combined with the mean atmospheric flux of $23.65 \pm 25.9 \mu \mathrm{mol} \mathrm{m}^{-2} \mathrm{~d}^{-1}$, gives an atmospheric input to $\mathrm{Fe}_{\mathrm{d}}$ equivalent to $710 \pm 777 \mathrm{nmol} \mathrm{m}^{-2} \mathrm{~d}^{-1}$ (range of 210-2712 nmol $\mathrm{m}^{-2} \mathrm{~d}^{-1}$ ). This estimate of the atmospheric input to $\mathrm{Fe}_{\mathrm{d}}$ concurs reasonably well with other values reported for the Pacific Ocean and Mediterranean Sea. For example, Johnson et al. (2003) reported atmospheric inputs to the $\mathrm{Fe}_{\mathrm{d}}$ in the northeastern Pacific Ocean of $800 \mathrm{nmol} \mathrm{m}^{-2} \mathrm{~d}^{-1}$, while Elbaz-Poulichet et al. (2001) and Guieu et al. (2002) reported values of 245-1324 $\mathrm{nmol} \mathrm{m}^{-2} \mathrm{~d}^{-1}$ for $\mathrm{Fe}_{\mathrm{d}}$ provided by atmospheric input to the western Mediterranean. Also for this latter region, Bonnet and Guieu (2006) reported an atmospheric Fe input of $170 \mathrm{nmol} \mathrm{m}^{-2} \mathrm{~d}^{-1}$.

Our atmospheric $\mathrm{Fe}_{\mathrm{d}}$ flux estimate indicates a significant input of this element to surface GC waters (figs. 3, 4, 6). This approximation, however, has its limitations considering that atmospheric particle input was measured between September 1997 and September 1998, under El Niño conditions, whereas the oceanographic cruise was conducted in May 2003, under more moderate El Niño conditions. This lack of synchrony between the collection of atmospheric particles and seawater sampling is a problem that has been dealt with before by other researchers (e.g., Jickells et al. 1987, Williams and Turekian 2002, Markaki et al. 2003, Bartoli et al. 2005, Schüßler et al. 2005). In the case of the GC, it is important to indicate that the

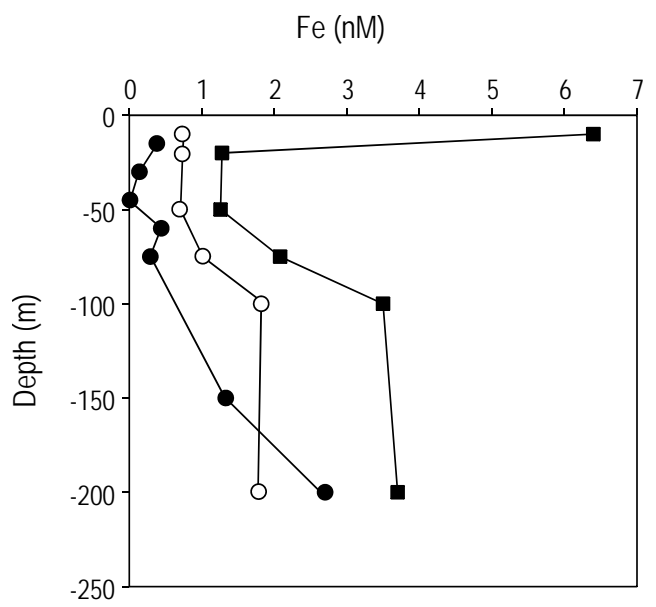

Figure 6. Comparison of the mean vertical profiles of $\mathrm{Fe}_{\mathrm{d}}$ in the northern zone (stations 3, 11, and 14; $\mathbf{-}$ ) and central-southern zone (stations 24, 28, 34 , and $38 ; 0$ ) of the study area with the Northeastern Pacific profile $(\bullet)$ located off the coast of Jalisco (Landing and Bruland 1987).

Figura 6. Comparación de los perfiles verticales promedio de $\mathrm{Fe}_{\mathrm{d}}$ de la región norteña $(3,11$ y 14; $\mathbf{\square})$, región central-sureña $(24,28,34$ y 38; O) contra el perfil del Pacífico Nororiental $(\bullet)$, localizado frente a las costas de Jalisco (Landing y Bruland 1987). estación en el estado de Sonora y sugirió que al menos $43 \%$ de los aportes eólicos contribuyen al flujo de material terrígeno estimado por Thunell (1998). Sin embargo, en el presente estudio una sola estación captadora de partículas atmosféricas no fue suficiente para reflejar la estacionalidad del flujo de partículas al GC. Por lo tanto, es de especial interés realizar estudios intensivos y con un número razonable de estaciones estratégicamente ubicadas tanto en la costa de Baja California como de Sonora, así como entre las islas, para establecer con mayor certidumbre la variabilidad espacial y temporal de los aportes atmosféricos de partículas al GC.

Los flujos atmosféricos de $\mathrm{Fe}_{\mathrm{p}}\left(7.0\right.$ a $\left.90.4 \mu \mathrm{mol} \mathrm{m}{ }^{-2} \mathrm{~d}^{-1}\right)$ fueron del mismo orden de magnitud que los reportados para el Mar Rojo (1.5 a $116 \mu \mathrm{mol} \mathrm{m}^{-2} \mathrm{~d}^{-1}$; Chase et al. 2006), el Océano Pacífico nororiental $\left(24 \mu \mathrm{mol} \mathrm{m}{ }^{-2} \mathrm{~d}^{-1}\right.$; Johnson et al. 2003) y el Mar Mediterráneo occidental $(39.98 \pm 3.80 \mu \mathrm{mol}$ $\mathrm{m}^{-2} \mathrm{~d}^{-1}$, Sarthou y Jeandel 2001; 10.70-54.6 $\mu \mathrm{mol} \mathrm{m} \mathrm{m}^{-2} \mathrm{~d}^{-1}$, Bonnet y Guieu 2006), pero más altos que los registrados para el Mar Mediterráneo noroccidental $\left(0.25-0.49 \mu \mathrm{mol} \mathrm{m}^{-2} \mathrm{~d}^{-1}\right.$; Guieu et al. 1997). En otras palabras, nuestros datos sugieren que el aporte de $\mathrm{Fe}_{\mathrm{p}}$ atmosférico al GC es importante, y éste dependerá de su solubilidad en el agua de mar. Experimentos de laboratorio han demostrado que la solubilidad del $\mathrm{Fe}$ varía entre 1-10\% (Spokes y Jickells 1996, Jickells y Spokes 2001). Para el Océano Pacífico nororiental, Johnson et al. (2003) estimó que la solubilidad del $\mathrm{Fe}$ fue de $3.33 \%$. Entonces, para el $\mathrm{GC}$, podemos suponer una solubilización de $3 \%$ para el $\mathrm{Fe}_{\mathrm{p}}$, que combinado con el flujo atmosférico medio de $23.65 \pm 25.9$ $\mu \mathrm{mol} \mathrm{m} \mathrm{m}^{-2} \mathrm{~d}^{-1}$, constituye un aporte atmosférico de $\mathrm{Fe}_{\mathrm{d}}$ equivalente a $710 \pm 777 \mathrm{nmol} \mathrm{m}^{-2} \mathrm{~d}^{-1}$ (un intervalo de 210 a 2712 $\mathrm{nmol} \mathrm{m} \mathrm{m}^{-2} \mathrm{~d}^{-1}$ ). Esta estimación del aporte atmosférico de $\mathrm{Fe}_{\mathrm{d}}$ está razonablemente de acuerdo con los valores reportados para el Océano Pacífico y el Mar Mediterráneo. Por ejemplo, Johnson et al. (2003) reportaron aportes atmosféricos de $\mathrm{Fe}_{\mathrm{d}}$ al Océano Pacífico nororiental de $800 \mathrm{nmol} \mathrm{m}^{-2} \mathrm{~d}^{-1}$. ElbazPoulichet et al. (2001) y Guieu et al. (2002) reportaron que el $\mathrm{Fe}_{\mathrm{d}}$ de origen atmosférico que entra al Mar Mediterráneo occidental es de 245 a $1324 \mathrm{nmol} \mathrm{m}^{-2} \mathrm{~d}^{-1}$, mientras que Bonnet y Guieu (2006) reportaron para la misma región un aporte atmosférico de Fe de $170 \mathrm{nmol} \mathrm{m}^{-2} \mathrm{~d}^{-1}$.

Nuestra estimación del aporte atmosférico de $\mathrm{Fe}_{\mathrm{d}}$ sugiere una entrada importante de este elemento al agua superficial del GC (figs. 3, 4, 6). No obstante, esta aproximación tiene sus limitaciones ya que debemos considerar que el aporte de partículas atmosféricas fue medido entre septiembre de 1997 y septiembre de 1998, en condiciones de El Niño, mientras que el muestreo oceanográfico se llevó a cabo en mayo de 2003, bajo condiciones más moderadas de El Niño. Esta falta de sincronía entre el muestreo de partículas atmosféricas y la recolecta de muestras de agua de mar es un problema que ya ha sido manejado anteriormente por otros investigadores (e.g., Jickells et al. 1987, Williams y Turekian 2002, Markaki et al. 2003, Bartoli et al. 2005, Schüßler et al. 2005). Sin embargo, en el caso del GC, es importante resaltar que la información en relación al flujo de partículas atmosféricas utilizada en este 
information pertaining to atmospheric particle flux used in this study (Delgadillo-Hinojosa et al. 2006) represents the only set of data available for the region. Also, analysis of wind patterns in the central-northern GC during May of 1997 and of 2003 (http://manati.orbit.nesdis.noaa.gov/quikscat/) indicated that during the 1998 El Niño event the winds intensified (approximately fourfold relative to those of May 2003), but did not show a notable change in direction (blowing from the Baja California Peninsula in both cases). It is thus reasonable to assume that the wind fluxes recorded in 1997-1998 probably represent an upper limit of the atmospheric fluxes of Fe entering the GC, while the $\mathrm{Fe}_{\mathrm{d}}$ data, obtained under near-average conditions in May 2003, represent the mean limit. Finally, in a study on the sedimentary and mineralogical origin of the northern GC after cessation of the Colorado River discharge, Carriquiry et al. (2001) found that material inputted into the $\mathrm{GC}$ is wind driven. These authors identifed four zones, among them a Baja California-Sonora province showing a similar mineralogical composition; hence, the composition of the atmospheric particles in our study could be equivalent and, therefore, independent of the location of the particle-catching station (in this case Kino Bay).

\section{Distribution of surface $\mathrm{Fe}_{\mathrm{d}}$}

The $\mathrm{Fe}_{\mathrm{d}}$ concentrations showed a wide range of variation $(0.07-7.21 \mathrm{nM})$, separated into a high concentration range $(5.57-7.21 \mathrm{nM})$ for the northern zone (stations 3,14 , and 11) and a low concentration range $(0.13-0.78 \mathrm{nM})$ for the centralsouthern zone (stations 24, 28, 34, and 38) of the study area (figs. 3, 6). This spatial variability can be explained by the different oceanographic regimes occurring in the central GC. The northern zone showed higher concentrations than those reported for the northeastern Pacific Ocean and similar to those in upwelling systems along the coast of California (Gordon et al. 1982, Landing and Bruland 1987, Martin and Gordon 1988, Bruland et al. 2001, Johnson et al. 2003). Maximum surface $\mathrm{Fe}_{\mathrm{d}}$ values have been recorded for Pacific, Atlantic, and Mediterranean waters, and have been attributed to external $\mathrm{Fe}$ sources, including river discharge (Bruland et al. 2001), atmospheric input (Bruland et al. 1994, Johnson et al. 2003), hydrothermal and benthic fluxes (Bruland 1983), and photochemical reduction processes (Duce and Tindale 1991). In the case of the GC, river input and benthic fluxes are probably not very important because of the scant freshwater discharge in the region (e.g., Carriquiry et al. 2001) and the wide separation in depth between the surface samples and the GC sediments $(>250 \mathrm{~m})$. Moreover, the profiles were taken in the central part of the GC, very far from river mouths, which for the most part have been dammed and discharge little freshwater into the region (Baumgartner et al. 1991, Carriquiry et al. 2001). Thus, surface $\mathrm{Fe}_{\mathrm{d}}$ enrichment in the northern zone is likely the result of a combination of factors, among them wind inputs and photoreduction processes, resulting in a concentration ratio of 9:1 relative to the southern zone (figs. 3, 6). trabajo (Delgadillo-Hinojosa et al. 2006), representa el único juego de datos disponible para toda la zona del GC. Asimismo, un análisis del patrón de los vientos en la región centro-norte del GC durante los meses de mayo de 1997 y de 2003 (http:// manati.orbit.nesdis.noaa.gov/quikscat/) indica que durante el evento de El Niño 1998, los vientos se intensificaron (aproximadamente cuatro veces en relación a los de mayo de 2003) pero no cambiaron sensiblemente de dirección (proviniendo de la Península de Baja California en ambos casos). Dadas estas condiciones, es razonable entonces esperar que los flujos eólicos obtenidos en 1997-1998 representen posiblemente un límite superior de los flujos atmosféricos de Fe que ingresan al $\mathrm{GC}$, mientras que los datos de $\mathrm{Fe}_{\mathrm{d}}$, tomados en condiciones cercanas a las medias en mayo de 2003, representarían el límite medio. Finalmente, es importante señalar que Carriquiry et al. (2001) realizaron una investigación sobre el origen sedimentario y mineralógico de la región norte del GC después del cierre del Río Colorado. Estos investigadores señalan que la entrada de material al GC es por vía eólica, y clasifican cuatro zonas, entre las cuales identifican una provincia Baja CaliforniaSonora que tiene una composición mineralógica similar, por lo que cabría esperar que la composición de las partículas atmosféricas para nuestro trabajo fuera equivalente y, por lo tanto, independiente de la ubicación de la estación captadora de partículas (en este caso, Bahía Kino).

\section{Distribución superficial de $F e_{\mathrm{d}}$}

Las concentraciones de $\mathrm{Fe}_{\mathrm{d}}$ presentaron un amplio intervalo de variación con valores que abarcaron de 0.07 a $7.21 \mathrm{nM}$. Este resultado se puede separar en un intervalo de alta concentración (5.57-7.21 nM) en la región norteña (estaciones 3, $14 \mathrm{y}$ 11) y otro de baja concentración $(0.13-0.78 \mathrm{nM})$ en la región centro-sur (estaciones 24, 28, 34 y 38) del área de estudio (figs. $3,6)$. Esta variabilidad espacial es producto de los diferentes regímenes oceanográficos que se presentan en la región central del GC. La región del norte presentó concentraciones más altas que las reportadas para el Océano Pacífico nororiental y similares a los sistemas de surgencias de la costa de California (Gordon et al. 1982, Landing y Bruland 1987, Martin y Gordon 1988, Bruland et al. 2001, Johnson et al. 2003). Los valores máximos de $\mathrm{Fe}_{\mathrm{d}}$ superficial que se presentan en los océanos Pacífico y Atlántico, y en el Mar Mediterráneo, han sido explicados por el efecto de fuentes externas de Fe como podrían ser aportes fluviales (Bruland et al. 2001) y atmosféricos (Bruland et al. 1994, Johnson et al. 2003), flujos hidrotermales y bénticos (Bruland 1983) y los procesos de reducción fotoquímicos (Duce y Tindale 1991). Para el GC, los aportes fluviales y el flujo béntico son probablemente de poca importancia dada la reducida descarga de agua dulce en la región (e.g., Carriquiry et al. 2001) y la gran separación en profundidad de las muestras de la capa superficial con los sedimentos del GC (>250 m). Además, los perfiles se midieron en la región media del GC y por lo tanto muy distantes de la desembocadura de los ríos, los cuales en su mayoría están represados y, en consecuencia, le aportan muy pocas descargas 
Dust deposition is recognized as an important geochemical path for inputs of particulate and dissolved $\mathrm{Fe}$ (as well as other trace elements) to the upper part of the open sea (e.g., Duce and Tindale 1991, Johnson et al. 1997, Moore and Braucher 2007). Photoreduction processes can also maintain high surface concentrations of $\mathrm{Fe}^{2+}$ (Johnson et al. 1994, Laglera and van der Berg 2007), neutralizing the removal of $\mathrm{Fe}^{2+}$ by oxidation to $\mathrm{Fe}^{3+}$ (Moffett 2001). Since our study did not contemplate the speciation of $\mathrm{Fe}$, it is not possible to determine the impact of photoreduction; however, considering that the GC receives solar light over more than $95 \%$ of the year (LariosCastillo 2009), Fe photoreduction in the photic zone is likely an important source of $\mathrm{Fe}_{\mathrm{d}}$ input to the water column. Delgadillo-Hinojosa et al. (2006) suggested that deposition of atmospheric particles and their subsequent photodissolution in situ may explain the vertical distribution of dissolved $\mathrm{Mn}$ in the GC. It can thus be assumed that, as in the case of Mn, Fe could also be affected by photoreduction processes that contribute to maintain high concentrations of $\mathrm{Fe}_{\mathrm{d}}$ in the surface layer. Despite the significant advances made in recent years in the study of trace metal distributions in the GC (DelgadilloHinojosa et al. 2006, Díaz-Rodríguez 2008, Domínguez-Rosas 2008), specific studies are still necessary to determine the effect of photoreduction reactions on the distribution of $\mathrm{Fe}$ in the gulf.

Surface enrichment in the northern zone of the study area could be associated with the input of $\mathrm{Fe}_{\mathrm{d}}$-enriched surface water originating in the upper GC. The surface $\mathrm{Fe}_{\mathrm{d}}$ concentration gradient shows higher values at the northern stations and lower at the southern stations, indicating the existence of a northern source (figs. 3, 4). Parallel research on dissolved Mn shows the same distribution pattern in the northern part of the study area (Díaz-Rodríguez 2008). It is therefore possible that the shallow continental shelf of the upper GC $(\sim 15 \mathrm{~m}$, Lavín et al. 1997) is, as a result of resuspension, one of the sources of surface enrichment in our study area. In support of this hypothesis, two mechanisms of $\mathrm{Fe}$ and $\mathrm{Mn}$ input to the water column have been reported for the northern GC: first, the low sedimentation speeds of clay particles $(\leq 4 \mu \mathrm{m})$ derived from the Colorado River delta, which are strongly associated with $\mathrm{Fe}$ and $\mathrm{Mn}$, and are frequently resuspended and redeposited in the northern GC (Daessle et al. 2002); second, the transport and redeposition of these particles, extending to the central Tiburón Basin (station 11; Daessle et al. 2002). More studies are needed to determine the relative importance of the factors responsible for surface enrichment in this area.

One way of quantitatively evaluating Fe surface enrichment is to compare the mean integrated concentration of the surface layer $(50 \mathrm{~m})$ of the northern and central-southern zones of the study area with the mean integrated concentration of the first $50 \mathrm{~m}$ of the adjacent Equatorial Pacific (Landing and Bruland 1987). Mean integrated concentration was $5.18 \mathrm{nM}$ for the northern zone (stations 3,11, and 14), $1.62 \mathrm{nM}$ for the central-southern zone (stations 24, 28, 34, and 38), and de agua dulce (Baumgartner et al. 1991, Carriquiry et al. 2001). Entonces, el enriquecimiento superficial de $\mathrm{Fe}_{\mathrm{d}}$ en la región norteña es probablemente el resultado de una combinación de factores, entre los que se pueden mencionar los aportes eólicos y procesos de fotorreducción, mismos que producen una mayor concentración, en una razón de 9:1, con relación a las estaciones sureñas (figs. 3, 6).

La depositación de polvo ha sido reportada como una ruta geoquímica importante para la entrada de Fe particulado y disuelto (y además de otros elementos traza) a la capa superior del océano abierto (e.g., Duce y Tindale 1991, Johnson et al. 1997, Moore y Braucher 2007). Los procesos de fotorreducción también pueden mantener las concentraciones superficiales de $\mathrm{Fe}^{2+}$ elevadas (Johnson et al. 1994, Laglera y van der Berg 2007) neutralizando la remoción de $\mathrm{Fe}^{2+}$ por su oxidación a Fe ${ }^{+3}$ (Moffett 2001). Desafortunadamente, nuestro estudio no contempló la especiación del Fe por lo que no es posible determinar el impacto de la fotorreducción. Sin embargo, el GC recibe luz solar durante más de $95 \%$ del año (Larios-Castillo datos no publicados), lo que sugiere que los procesos de fotorreducción del $\mathrm{Fe}$ en la zona fótica podrían ser vías importantes de aporte de $\mathrm{Fe}_{\mathrm{d}}$ a la columna de agua superficial del GC. Delgadillo-Hinojosa et al. (2006) sugirieron que la depositación eólica de partículas y su subsecuente fotodisolución in situ podría explicar la distribución vertical de manganeso disuelto $\left(\mathrm{Mn}_{\mathrm{d}}\right)$ en el GC. Es razonable entonces suponer que, al igual que para el caso del Mn, el Fe también podría ser afectado por procesos de fotorreducción que contribuyen a mantener concentraciones elevadas de $\mathrm{Fe}_{\mathrm{d}}$ en la capa superficial. Si bien es cierto que en años recientes se han realizado avances significativos en el estudio de las distribuciones de metales traza en el GC (Delgadillo-Hinojosa et al. 2006, Díaz-Rodríguez 2008, Domínguez-Rosas 2008), también es cierto que se requieren estudios específicos para evaluar la importancia de las reacciones de fotorreducción sobre la distribución de Fe en el GC.

Un mecanismo que debe ser considerado para el enriquecimiento superficial de la región norteña, es la entrada de agua superficial enriquecida con $\mathrm{Fe}_{\mathrm{d}}$ que se origina y proviene de la región norte del alto GC. Lo anterior es congruente con el gradiente superficial de concentración de $\mathrm{Fe}_{\mathrm{d}}$, que muestra valores altos en el norte y disminuye hacia las estaciones sureñas indicando que hay una fuente que proviene del norte (figs. 3, 4). Una investigación paralela sobre $\mathrm{Mn}$ disuelto presenta el mismo patrón de distribución en la parte norte del área de estudio (Díaz-Rodríguez 2008). Por lo tanto, es muy posible que la somera plataforma continental del alto Golfo de California ( $\sim 15 \mathrm{~m}$; Lavin et al. 1997) sea, debido a la resuspension, una de las fuentes del enriquecimiento superficial detectado en este estudio. En apoyo a esta hipótesis, en la parte norte del GC se reportan dos mecanismos que aportan Fe y Mn a la columna de agua: el primero son las bajas velocidades de sedimentación de las partículas de arcilla $(\leq 4 \mu \mathrm{m})$ derivadas del delta del Río Colorado, las cuales están fuertemente asociadas al Fe y Mn, y son frecuentemente resuspendidas y redepositadas en el norte del GC (Daessle et al. 2002); el segundo es el transporte de 
$0.22 \mathrm{nM}$ for the Northeastern Pacific, indicating that the enrichment factors are 23.5 and 7.4 higher in the GC than in the adjacent Pacific Ocean. These enrichment factors are high for spring, but they could increase significantly during summer when the lithogenic flux is even higher (Thunell 1998). Regardless of whether the atmospheric particle time series was taken in 1997-1998, the May 2003 wind pattern and wind deposition suggest an important source of continental origin that must affect the surface distribution of $\mathrm{Fe}_{\mathrm{d}}$, which in this study can be identified as typical surface enrichment (figs. 3, 4, 6). Moreover, it is logical to assume that the concentrations of $\mathrm{Fe}_{\mathrm{d}}$ during El Niño events are significantly higher.

\section{Removal and photosynthesis}

Vertical profiles of $\mathrm{Fe}$ in the ocean define processes that are occurring across the water column, such as those due to atmospheric input, biological uptake and removal within the photic zone, and mixing processes (Bruland et al. 1994, Wu et al. 2001). In the northern zone of our study area, in addition to the effects of atmospheric input and possible photoreduction, the decrease in $\mathrm{Fe}_{\mathrm{d}}$ at 20-50 m depth could be due to processes that remove or consume $\mathrm{Fe}_{\mathrm{d}}$. The vertical distribution of $\mathrm{Fe}_{\mathrm{d}}$ showed a mixed behavior (fig. 5a), decreasing in concentration between 20 and $50 \mathrm{~m}$ and then increasing with depth. In the Pacific Ocean, $\mathrm{Fe}_{\mathrm{p}}$ fluxes increase with depth (Landing and Bruland 1987), suggesting removal of Fe from dissolved to particulate phase. As we lacked data of $\mathrm{Fe}_{\mathrm{p}}$ in the water column we were unable to make an association between both forms of $\mathrm{Fe}$, though Chla concentrations suggested possible removal of $\mathrm{Fe}_{\mathrm{d}}$ to the particulate phase. On the other hand, the increase in $\mathrm{Fe}_{\mathrm{d}}$ at greater depths indicates input associated with the remineralization of organic matter (fig. 5a). For the northern zone, if the 10 and $20 \mathrm{~m}$ depths are not considered, high correlations are obtained for $\mathrm{Fe}: \mathrm{NO}_{3}(r=0.95), \mathrm{Fe}: \mathrm{O}_{2}(r=-0.97)$, and Fe:Chla $(r=-0.80)$, suggesting that $\mathrm{Fe}_{\mathrm{d}}$ is involved in the remineralization processes of organic matter.

The southern zone, however, with no sign of atmospheric input, only showed a nutrient-type distribution (fig. 5b), with $\mathrm{Fe}_{\mathrm{d}}$ correlating positively (0.86) and negatively $(r=-0.87$ and $r=-0.79$ ) with $\mathrm{NO}_{3}, \mathrm{O}_{2}$, and Chla, respectively ( $n=6$; fig. $5 \mathrm{~b}$ ). This same behavior was observed in the northeastern Pacific Ocean, where the typical vertical distribution of $\mathrm{Fe}_{\mathrm{d}}$ first shows low concentrations in surface waters, then concentrations that increase regularly with depth, and finally maximum concentrations associated with the $\mathrm{O}_{2}$ minimum zone (Martin and Gordon 1988). This distribution profile indicates that $\mathrm{Fe}$ is consumed by phytoplankton in surface waters, while maximum $\mathrm{Fe}_{\mathrm{d}}$ within the $\mathrm{O}_{2}$ minimum zone is due to the decomposition of organic matter. It is precisely during this process that $\mathrm{O}_{2}$ is consumed, and $\mathrm{CO}_{2}, \mathrm{NO}_{3}$, and $\mathrm{Fe}^{2+}$ are regenerated (Martin and Gordon 1988). The correlation with $\mathrm{NO}_{3}$, a limiting nutrient, suggests a coupling of Fe with the oceanic biological cycle (Martin et al. 1989, Measures and Vink 2001). esas partículas y su redepositación, que se extiende hasta el centro de la Cuenca Tiburón (estación 11; Daessle et al. 2002). Sin embargo, es necesario realizar más estudios en esta zona para determinar la importancia relativa de los factores responsables del enriquecimiento superficial.

Una manera de evaluar cuantitativamente el enriquecimiento superficial de $\mathrm{Fe}$ es comparar las concentraciones medias integradas de la capa superficial $(50 \mathrm{~m})$ de la región norteña (estaciones 3,11 y 14) y de la región centro-sur (estaciones $24,28,34$ y 38 ) con la concentración media integrada de los primeros $50 \mathrm{~m}$ del Pacífico Nororiental adyacente (Landing y Bruland 1987). La concentración media integrada de la región norteña fue de $5.18 \mathrm{nM}$, la de la región centro-sur de $1.62 \mathrm{nM}$ y la del Pacífico Nororiental fue de $0.22 \mathrm{nM}$. Estos resultados nos indican que los factores de enriquecimiento son 23.5 y 7.4 veces más altos en el GC que en el Océano Pacífico adyacente. Estos factores de enriquecimiento de por sí son elevados para el estudio de primavera, pero podrían incrementarse significativamente durante la época de verano, cuando el flujo litogénico es aún mayor (Thunell 1998). Independientemente de que la serie de tiempo de aportes particulados atmosféricos fuera obtenida en 1997-1998, el patrón de vientos durante mayo de 2003 y la depositación eólica sugieren una fuente importante de origen continental que necesariamente debería afectar la distribución superficial de $\mathrm{Fe}_{\mathrm{d}}$, lo cual puede identificarse en este trabajo como un típico enriquecimiento superficial (figs. 3, 4, 6). Además, es lógico suponer que las concentraciones de $\mathrm{Fe}_{\mathrm{d}}$ durante eventos El Niño sean significativamente mayores.

\section{Remoción y fotosíntesis}

Los perfiles verticales del Fe en el océano se han caracterizado por definir procesos que están ocurriendo a través de la columna de agua, como los debidos a los aportes atmosféricos, a la captación biológica y a la remoción dentro de la zona fótica, así como a los procesos de mezcla (Bruland et al. 1994, Wu et al. 2001). Para el caso específico de la región norteña del GC, además de los efectos de la entrada atmosférica y la posible fotoreducción, es posible que la disminución del $\mathrm{Fe}_{\mathrm{d}}$ a los $20-50 \mathrm{~m}$ de profundidad sea debida a procesos que remuevan o consuman el $\mathrm{Fe}_{\mathrm{d}}$. En la figura 5a se puede observar que la distribución vertical tiene un comportamiento mixto, ya que entre los 20 y $50 \mathrm{~m}$ el Fe $e_{\mathrm{d}}$ presenta una disminución en su concentración y después de esta profundidad se presenta un incremento. $\mathrm{Se}$ ha reportado que los flujos de $\mathrm{Fe}_{\mathrm{p}}$ aumentan con la profundidad en el Océano Pacífico (Landing y Bruland 1987), sugiriendo remoción de $\mathrm{Fe}_{\mathrm{d}}$ hacia la fase particulada. En nuestro trabajo no contamos con datos de $\mathrm{Fe}_{\mathrm{p}}$ en la columna de agua para poder realizar una asociación entre ambas formas de $\mathrm{Fe}$, aunque las concentraciones de Chla sugieren una posible remoción del $\mathrm{Fe}_{\mathrm{d}}$ al particulado. En contraste, el incremento del $\mathrm{Fe}_{\mathrm{d}}$ hacia mayores profundidades sugiere un aporte asociado a la remineralización de la materia orgánica (fig. 5a). Para la región norte, si no consideramos las profundidades de 10 y 20 $\mathrm{m}$, se obtienen correlaciones elevadas para Fe: $\mathrm{NO}_{3}(r=0.95)$, 


\section{Mixing}

Physical processes in the central GC play an important role in the hydrodynamics and distribution of nutrients and trace metals. For example, in the region of the large islands, high rates of primary productivity are produced by an increase in the availability of inorganic nutrients in the surface layer caused by tidal pumping (Santamaría-del Ángel and Álvarez-Borrego 1994). In the same region, Cd (Delgadillo-Hinojosa et al. 2001, Domínguez-Rosas 2008) and Mn (Delgadillo-Hinojosa et al. 2006, Díaz-Rodríguez 2008) are affected by mixing processes. This suggests that the vertical isolines of $\mathrm{Fe}_{\mathrm{d}}(1$ and $2 \mathrm{nM})$ between stations 11 and 24 (fig. 4) are the result of mixing processes and upwelling of subsurface water, represented by the rising of the $4 \mathrm{nM}$ isoline from 300 to $100 \mathrm{~m}$ and of the $2 \mathrm{nM}$ isoline from $200 \mathrm{~m}$ to the surface (fig. 4). One way of establishing the effect of vertical mixing is by using the $\Phi$ parameter (Simpson et al. 1977), which calculates the mechanical energy required to vertically mix a water column. This parameter (in $\mathrm{J} \mathrm{m}^{-3}$ ) is given by

$$
\Phi=\left(\frac{1}{h}\right)_{-H}^{0}(\bar{\rho}-\rho) g z d z
$$

where $\bar{\rho}=\left(\frac{1}{h}\right) \int_{-H}^{0} \rho d z$ is the mean density of water, $H$ the integrated depth, $z$ the depth, $\rho$ the density, and $g$ the acceleration due to gravity.

The $\Phi$ estimates were $33 \mathrm{~J} \mathrm{~m}^{-3}$ for station 24 (located above San Esteban Sill), $85 \mathrm{~J} \mathrm{~m}^{-3}$ for station 3 (northernmost station), and $172 \mathrm{~J} \mathrm{~m}^{-3}$ for station 38 (southernmost station). These results indicate that the mixed water column at station 24 requires less mechanical energy as indicated by the $2 \mathrm{nM}$ isoline of $\mathrm{Fe}_{\mathrm{d}}$ (fig. 4). In contrast, the stratified water columns at stations 3 and 38 require more than double (2.6-5.2 times) the mechanical energy for vertical mixing than the station 24 water column. Another way of determining mixing is to observe the vertical variability of the concentration at stations close to station 24. For example, at station 11, surface $\mathrm{Fe}_{\mathrm{d}}$ decreases from 6.42 to $1.61 \mathrm{nM}$ between 10 and $50 \mathrm{~m}$ depth, whereas at stations 24 and 28, similar concentrations were recorded at $200 \mathrm{~m}$ depth (table 1). These values indicate a clear reduction in the vertical variability of $\mathrm{Fe}_{\mathrm{d}}$ concentration in surface waters in the vicinity of San Esteban Sill, suggesting intense mixing down to $200 \mathrm{~m}$ depth (station 24; fig. 4). At station 24, the mean integrated concentration of $\mathrm{Fe}_{\mathrm{d}}(0.44 \mathrm{nM})$ for the top $100 \mathrm{~m}$ of depth was significantly lower than that recorded for the rest of the stations ( $1.97 \pm 0.91 \mathrm{nM}, n=6$, stations 3 to $38, P<0.05)$. This result shows that, in general, the six vertical profiles were relatively homogeneous in the upper $200 \mathrm{~m}$, and that vertical tidal mixing at station 24 plays an important role in controlling the vertical distribution of $\mathrm{Fe}_{\mathrm{d}}$. Tidal advection and the vertical mixing that normally occurs around San Esteban Island and
$\mathrm{Fe}: \mathrm{O}_{2}(r=-0.97)$ y Fe:Chla $(r=-0.80)$, lo que sugiere que el $\mathrm{Fe}_{\mathrm{d}}$ está involucrado en los procesos de remineralización de la materia orgánica.

Sin embargo, la región sur (estaciones 28, 34 y 38), que no mostró la señal de aporte atmosférico, sólo presentó una distribución tipo nutriente del $\mathrm{Fe}_{\mathrm{d}}$ (fig. 5b), en donde éste se correlacionó positiva (0.86) y negativamente $(r=-0.87$ y $r=-0.79)$ con los $\mathrm{NO}_{3}$, el oxígeno y la clorofila, respectivamente $(n=6$; fig. 5b). Este mismo comportamiento fue observado en el Océano Pacífico nororiental, en donde la distribución típica vertical de $\mathrm{Fe}_{\mathrm{d}}$ muestra concentraciones bajas en aguas superficiales, luego concentraciones que se incrementan regularmente con la profundidad, y, finalmente, concentraciones máximas asociadas con la zona del mínimo de $\mathrm{O}_{2}$ disuelto (Martin y Gordon 1988). Este perfil de distribución indica que el Fe es consumido por el fitoplancton en aguas superficiales, mientras que el máximo de $\mathrm{Fe}$ disuelto dentro del mínimo de $\mathrm{O}_{2}$ es resultado de la descomposición de la materia orgánica. Es precisamente durante este proceso que el $\mathrm{O}_{2}$ es consumido y $\mathrm{CO}_{2}$, $\mathrm{NO}_{3}$ y $\mathrm{Fe}^{2+}$ son regenerados (Martin y Gordon 1988). La correlación con los $\mathrm{NO}_{3}$, que son nutrientes limitantes, sugiere el acoplamiento del Fe con el ciclo biológico oceánico (Martin et al. 1989, Measures y Vink 2001).

\section{Mezcla}

Se ha reportado que en la región central del GC los procesos físicos son un factor importante en la hidrodinámica y en la distribución de los nutrientes y los metales traza. Por ejemplo, en la región de las grandes islas del GC las altas tasas de producción primaria son generadas por el aumento en la disponibilidad de nutrientes inorgánicos en la capa superficial, el cual es provocado por el proceso de bombeo por mareas (Santamaría del Ángel y Álvarez-Borrego 1994). En la misma región, Cd (Delgadillo-Hinojosa et al. 2001, Domínguez-Rosas 2008) y Mn (Delgadillo-Hinojosa et al. 2006, Díaz-Rodríguez 2008) son afectados por procesos de mezcla. Lo anterior sugiere que las isolíneas verticales de $\mathrm{Fe}_{\mathrm{d}}(1 \mathrm{y} 2 \mathrm{nM})$ entre las estaciones 11 y 24 (fig. 4) son consecuencia de procesos de mezcla y surgencias de agua subsuperficial, representados por la elevación de la isolínea de $4 \mathrm{nM}$ de los 300 a los $100 \mathrm{~m}$ superficiales, y de la de $2 \mathrm{nM}$ que se levanta desde los $200 \mathrm{~m}$ hasta la superficie (fig. 4). Una manera de establecer el efecto de la mezcla vertical es utilizando el parámetro $\Phi$ de Simpson et al. (1977), el cual calcula la energía mecánica que se requiere para mezclar verticalmente una columna de agua. Este parámetro (en $\mathrm{J} \mathrm{m}^{-3}$ ) está dado por

$$
\Phi=\left(\frac{1}{h}\right) \int_{-H}^{0}(\bar{\rho}-\rho) g z d z
$$

donde $\bar{\rho}=\left(\frac{1}{h} \int_{-H}^{0} \rho d z\right.$ es la densidad media del agua, $H$ la profundidad integrada, $z$ la profundidad, $\rho$ la densidad y $g$ la aceleración gravitacional. 
the sill produce lower surface concentrations than at nearby stations. Hence, the $\mathrm{Fe}_{\mathrm{d}}$ profiles observed in this study were generated by complex interactions involving atmospheric input, biological uptake, in situ removal-remineralization of particles, advection, and mixing.

\section{Implications of extraordinary atmospheric Fe inputs}

What are the possible implications of extraordinary inputs of atmospheric particles to the Gulf of California caused by events such as the 1998 El Niño? In general, atmospheric inputs can significantly affect biogeochemical cycles in the GC in different ways. According to Jickells et al. (2005), there is evidence of luxury Fe uptake by some phytoplankton species, a strategy that allows them to better adapt to periodic atmospheric inputs (Kustka et al. 2003). These unusual inputs can potentially change the structure of the algal community and, consequently, the general productivity of the GC. Should this condition occur in the GC, atmospheric dust would probably also input macro- and micronutrients (e.g., P) to the mixed surface layer, especially under seasonal conditions characterized by a stratified water column and low productivity (e.g., Bonnet and Guieu 2006). For example, Pulido-Villena et al. (2008) report that during a stratified period in the Mediterranean Sea, increases of $50 \%$ and $100 \%$ were oberved in bacterial abundance and respiration, respectively, induced by a Saharan dust event. Extraordinary Fe inputs under stratified column and low productivity conditions in the study area (favoring high temperatures and irradiances, and low nitrate concentrations in surface waters) could increase the biomass of Trichodesmium, a photosynthetic diazotroph requiring 5-10 times more Fe for its growth based on $\mathrm{N}_{2}$ fixation, when compared to growth based on ammonium (Kustka et al. 2003). This condition could feasibly occur in the northern $\mathrm{GC}$ in summer (temperatures $>30^{\circ} \mathrm{C}$; Bray 1988, Soto-Mardones et al. 1999) and during a period of neap tides (stratified water column). Finally, atmospheric particles could have a direct influence on Fe export to deep GC waters via the ballast effect (Jickells et al. 2005). Should this occur, an important part of the $\mathrm{Fe}$ associated with the atmospheric dust would be preserved (due to the low solubility of $\mathrm{Fe}$ ) and subsequently released in deep waters of the GC, resulting in an increase in $\mathrm{Fe}_{\mathrm{d}}$ concentrations.

\section{Acknowledgements}

This study was financed by CONACYT (grants SEP-2004C01-46576, SEP-46523, and SEP-G33464-T) and the University of Baja California (UABC project 565). We thank S Sañudo-Wilhelmy for giving us access to the ultra-clean laboratory and ICP-MS, and V Camacho for providing the nitrate analysis. We also thank A Pares-Sierra for the maps of winds for El Niño 1997-1998 period.

English translation by Christine Harris.
Los cálculos de $\Phi$ para la estación 24, localizada por encima del Umbral de San Esteban, fue de $33 \mathrm{~J} \mathrm{~m}^{-3}$ y para las estaciones localizadas en los extremos norte (estación 3 ) y sur (estación 38) del área de estudio fueron $\Phi=85 \mathrm{y} 172 \mathrm{~J} \mathrm{~m}^{-3}$, respectivamente. Estos resultados indican que la columna de agua en la estación 24 requiere de menor energía mecánica (por estar mezclada), lo cual se manifiesta por la isolínea de 2 $\mathrm{nM}$ de $\mathrm{Fe}_{\mathrm{d}}$ (fig. 4). En contraste, las columnas de agua de las estaciones 3 y 38, que están estratificadas, requieren de más del doble (2.6-5.2 veces) de energía mecánica para su mezcla vertical que la columna de agua de la estación 24. Otra forma de notar la mezcla es observando la variabilidad vertical de la concentración en estaciones aledañas a la estación 24. Por ejemplo, en la estación $11 \mathrm{el} \mathrm{Fe}_{\mathrm{d}}$ superficial disminuye de 6.42 a $1.61 \mathrm{nM}$ de 10 a $50 \mathrm{~m}$ de profundidad, mientras que en las estaciones 24 y 28 se registraron concentraciones similares a los $200 \mathrm{~m}$ de profundidad (tabla 1). Estos valores indican que en aguas superficiales se presenta una clara reducción de la variabilidad vertical de la concentración de $\mathrm{Fe}_{\mathrm{d}}$ en los alrededores de la zona del Umbral de San Esteban, lo que indica un intensa mezcla hasta los $200 \mathrm{~m}$ (estación 24; fig. 4). Por ejemplo, en la estación 24, la concentración media integrada de $\mathrm{Fe}_{\mathrm{d}}$ $(0.44 \mathrm{nM})$ para los $100 \mathrm{~m}$ superficiales fue significativamente menor que la obtenida para el resto de las estaciones (1.97 \pm $0.91 \mathrm{nM} \mathrm{n}=6$; estaciones 3 a 38; $P<0.05$ ). Este resultado sugiere que, en general, los seis perfiles verticales de $\mathrm{Fe}_{\mathrm{d}}$ fueron relativamente homogéneos en los $200 \mathrm{~m}$ superiores, mientras que la mezcla vertical por marea en la estación 24 juega un papel importante en el control de su distribución vertical. Así mismo, la mezcla vertical normalmente presente en la Isla San Esteban y la región de su umbral, junto con la advección por mareas, produce concentraciones menores en las aguas superficiales en relación a las estaciones aledañas. Luego entonces, los perfiles de $\mathrm{Fe}_{\mathrm{d}}$ en este estudio son generados por un complicado balance entre el aporte atmosférico superficial, la captación biológica, la remoción-remineralización de partículas in situ, la advección y la mezcla.

\section{Implicaciones de aportes extraordinarios de partículas eólicas con Fe}

¿Cuáles pueden ser las implicaciones de aportes extraordinarios de partículas eólicas al Golfo de California, ocasionados por eventos como El Niño ocurrido en 1998? En general, los aportes atmosféricos pueden afectar de manera importante los ciclos biogeoquímicos del GC de diferentes maneras. De acuerdo a Jickells et al. (2005), se ha comprobado una asimilación en exceso abundante de Fe por parte de algunas especies de fitoplancton, lo que les permite una mejor adaptación a los abastecimientos atmosféricos periódicos (Kustka et al. 2003). En otras palabras, estos aportes periódicos extraordinarios de partículas atmosféricas pueden tener el potencial de cambiar la estructura de la comunidad algal y, por consiguiente, la productividad en general del GC. En caso de que esta condición se presente en el GC, es posible también que el polvo atmosférico 


\section{References}

Álvarez-Borrego S, Lara-Lara R. 1991. The physical environment and primary productivity of the Gulf of California. In: Dauphin JP, Simoneit BR (eds.), The Gulf Peninsular Province of the Californias. American Association of Petroleum Geologists Mem. 47, pp. 555-567.

Bartoli G, Migon C, Losno R. 2005. Atmospheric input of dissolved inorganic phosphorus and silicon to the coastal northwestern Mediterranean Sea: Fluxes, variability and possible impact on phytoplankton dynamics. Deep-Sea Res. (Part I) 52: 2005-2016.

Baumgartner TR, Ferreira-Bartrina V, Moreno-Hentz P. 1991. Varve formation in the central Gulf of California: A reconsideration of the origin of the dark laminae from the 20th century varve record. In: Dauphin JP, Simoneit BR (eds.), The Gulf and Peninsular Province of the Californias. American Association of Petroleum Geologists Mem. 47, pp. 617-635.

Bernhardt H, Wilhelms A. 1967. The continuous determination of low level iron, soluble phosphate and total phosphate with the AutoAnalyzer. Technicon Symp., 1967, Vol. I, 386 pp.

Bonnet S, Guieu C. 2006. Atmospheric forcing on the annual iron cycle in the western Mediterranean Sea: A one-year survey. J. Geophys. Res. Vol. 111, C09010, doi: 10.1029/2005JC003213.

Bray NA. 1988. Thermohaline circulation in the Gulf of California. J. Geophys. Res. 93: 4993-5020.

Bray N, Robles JM. 1991. Physical oceanography of the Gulf of California. In: Dauphin JP, Simoneit BR (eds.), The Gulf and Peninsular Province of the Californias. American Association of Petroleum Geologists Mem. 47, pp. 511-553.

Bruland KW. 1983. Trace elements in sea-water. In: Riley JP, Chester R (eds.), Chemical Oceanography. Academic Press, London, pp. 157-220.

Bruland KW, Franks RP, Knauer GA, Martin JH. 1979. Sampling and analytical methods for the determination of copper, cadmium, zinc and nickel at the nanogram per 1 level in seawater. Anal. Chim. Acta 105: 233-245.

Bruland KW, Orians KJ, Cowen JP. 1994. Reactive trace metals in the stratified central North Pacific. Geochim. Cosmochim. Acta 58: 3171-3182.

Bruland KW, Rue AL, Smith GJ. 2001. Iron and macronutrients in California coastal upwelling regimes: Implications for diatom blooms. Limnol. Oceanogr. 46: 1661-1674.

Carpenter JH. 1965. The Chesapeake Bay Institute technique for the micro Winkler dissolved oxygen method. Limnol. Oceanogr. 10: $141-143$

Carriquiry JD, Sanchez A, Camacho-Ibar VF. 2001. Sedimentation in the northern Gulf of California after cessation of the Colorado River discharge. Sediment. Geol. 144: 37-62.

Chase Z, Paytan A, Johnson KS, Street J, Chen Y. 2006. Input and cycling of iron in the Gulf of Aqaba, Red Sea. Global Biogeochem. Cycles 20, GB3017, doi: 10.1029/2005GB002646.

Coale KH, Johnson KS, Fitzwater SE, Gordon RM. 1996. A massive phytoplankton bloom induced by an ecosystem-scale iron fertilization experiment in equatorial Pacific Ocean. Nature 383: 495-501.

Cullen JT, Sherrell RM. 1999. Techniques for determination of trace metals in small samples of size-fractionated particulate matter: Phytoplankton metals off central California. Mar. Chem. 67: 233-247.

Daessle LW, Ramos SE, Carriquiry JD, Camacho-Ibar VF. 2002. Clay dispersal and the geochemistry of manganese in the northern Gulf of California. Cont. Shelf Res. 22: 1311-1323.

Delgadillo-Hinojosa F. 2000. Biogeoquímica del cadmio y manganeso en el Golfo de California. Ph.D. thesis, Universidad Autónoma de Baja California, Ensenada, Mexico, 181 pp. aporte macro y micronutrientes (e.g., P) a la capa de mezcla superficial, especialmente en condiciones estacionales caracterizadas por una columna de agua estratificada y baja productividad (e.g., Bonnet y Guieu 2006). Por ejemplo, de acuerdo con Pulido-Villena et al. (2008) durante el periodo de estratificación del Mar Mediterráneo se detectaron incrementos de $50 \%$ y $100 \%$ en la abundancia y respiración bacteriana, respectivamente, inducidos por un evento de polvo del Sahara. Aportes extraordinarios de Fe con una columna de agua estratificada y baja productividad en la zona de estudio (las cuales favorecen altas temperaturas e irradiancias, y bajas concentraciones de nitrato en las aguas superficiales) podrían incrementar la biomasa de Trichodesmium, diazotrofo fotosintético que requiere de 5 a 10 veces más $\mathrm{Fe}$ para su crecimiento basado en la fijación de $\mathrm{N}_{2}$, cuando se le compara con el basado en amonio (Kustka et al. 2003). Es muy factible que esta condición se dé en la región norte del GC durante el verano (altas temperaturas $>30^{\circ} \mathrm{C}$; Bray 1988 , Soto-Mardones et al. 1999) y en periodo de mareas muertas (columna de agua estratificada). Finalmente, las partículas atmosféricas podrían tener una influencia directa en la exportación de Fe a las aguas profundas del GC a través del llamado "efecto lastre" (Jickells et al. 2005). Bajo este esquema, una porción importante del Fe asociado al polvo atmosférico sería preservada (debido a la baja solubilidad del Fe) y liberada posteriormente en las aguas profundas del GC, en donde ocasionaría un incremento en las concentraciones de $\mathrm{Fe}_{\mathrm{d}}$.

\section{Agradecimientos}

Este estudio fue realizado gracias al financiamiento del CONACYT (códigos SEP-2004-C01-46576, SEP-46523 y SEP-G33464-T, así como del proyecto interno de la Novena Convocatoria de Apoyo a Proyectos de Investigación de la Universida Autónoma de Baja California (programa UABC 565). Agradecemos a S Sañudo-Wilhelmy quien facilitó el acceso a su laboratorio ultralimpio y al ICP-MS, y a V Camacho quien proveyó el análisis de nitratos. También se agradece a A Parés-Sierra por los mapas de vientos del período Niño 97-98.

Delgadillo-Hinojosa F, Macías-Zamora JV, Segovia-Zavala JA, Torres-Valdés S. 2001. Cadmium enrichment in the Gulf of California. Mar. Chem. 75: 109-122.

Delgadillo-Hinojosa F, Segovia-Zavala JA, Huerta-Díaz MA, AtilanoSilva H. 2006. Influence of geochemical and physical processes on the vertical distribution of manganese in Gulf of California waters. Deep-Sea Res. (Part I) 53: 1301-1319.

Díaz-Rodríguez G. 2008. Estudio de la distribución vertical de manganeso y cobalto en la región de las grandes islas del Golfo de California. M.Sc. thesis, Universidad Autónoma de Baja California, Ensenada, Mexico, $91 \mathrm{pp}$.

Domínguez-Rosas A. 2008. Distribución vertical y temporal de níquel y cadmio en el Golfo de California. M.Sc. thesis, Universidad Autónoma de Baja California, Ensenada, Mexico, 97 pp.

Douglas MW, Maddox RW, Howard K, Reyes S. 1993. The Mexican monsoon. J. Clim. 6: 1665-1677. 
Duce RA, Tindale NW. 1991. Atmospheric transport of iron and its disposition in the ocean. Limnol. Oceanogr. 36: 1715-1726.

Elbaz-Poulichet F, Guieu C, Morley NH. 2001. A reassessment of trace metal budgets in the western Mediterranean Sea. Mar. Pollut. Bull. 42: 623-627.

Gordon RM, Martin JH, Knauer GA 1982. Iron in northeast Pacific waters. Nature 229: 611-612.

Guieu C, Chester R, Ninmo N, Martin JM, Guerzoni S, Nicolas E, Mateu J, Keyse S. 1997. Atmospheric input of dissolved and particulate metals to the northwestern Mediterranean. Deep-Sea Res. (Part II) 44(3-4): 655-674.

Guieu C, Loye-Pilot MD, Ridame C, Thomas C. 2002. Chemical characterization of the Saharan dust end-member: Some biogeochemical implications for the western Mediterranean Sea. J. Geophys. Res. 107(D15), 10.1029/2001JD000582.

Holm-Hansen O, Holmes RW, Strickland JDH. 1965. Fluorometric determination of chlorophyll. J. Cons. Int. Explor. Mer 30: 3-15.

Jickells TD, Spokes LJ. 2001. Atmospheric iron inputs on the oceans. In: Turner DR, Hunter KA (ed.), The Biogeochemistry of Iron in Seawater. John Wiley, New York, pp. 86-121.

Jickells TD, Church TM, Deuser WG. 1987. A comparison of atmospheric inputs and deep-ocean particle fluxes for the Sargasso Sea. Global Biogeochem. Cycles 1: 117-130.

Jickells TD, An ZS, Andersen KK, Baker AR, Bergametti G, Brooks N, Cao JJ, Boyd PW, Duce RA, Hunter KA, Kawahata H, Kubilay N, laRoche J, Liss PS, Mahowald N, Prospero JM, Ridgwell AJ, Tegen I, Torres R. 2005 Global iron connections between desert dust, ocean biogeochemistry, and climate. Science 308: 67-71.

Johnson KS, Coale KH, Elrod VA, Tidale NW. 1994. Iron photochemistry in the equatorial Pacific. Mar. Chem. 46: 319-334.

Johnson KS, Gordon RM, Coaled KH. 1997. What controls dissolved iron concentrations in the world ocean? Mar. Chem. 57: 137-161.

Johnson KS, Elrod VA, Fitzwater SE, Plant JN, Chavez FP, Tanner SJ, Gordon RM, Westphal DL, Perry KD, Wu J, Karl DM. 2003. Surface ocean-lower atmosphere interactions in the northeast Pacific Ocean Gyre: Aerosols, iron and the ecosystem response. Global Biogeochem. Cycles 17(2), 1063, doi: 10.1029/ 2002 GB002004.

Kustka AB, Sañudo-Wilhelmy SA, Carpenter EJ, Capone D, Burns J, Sunda WG. 2003 Iron requirements for dinitrogen- and ammonium-supported growth in cultures of Trichodesmium (IMS 101): Comparison with nitrogen fixation rates and iron:carbon ratios of field populations. Limnol. Oceanogr. 48: 1869-1884.

Laglera LM, van den Berg CM. 2007. Wavelength dependence of the photochemical reduction of iron in Arctic seawater. Environ. Sci. Technol. 41: 2296-3002.

Landing WM, Bruland KW. 1987. Contrasting biogeochemistry of iron and manganese in the Pacific Ocean. Geochim. Cosmochim. Acta 51: 29-43.

Landing WM, Lewis BL. 1991. Collection, processing, and analysis of marine particulate and colloidal material for transition metals. In: Marine Particles: Analysis and Characterization. American Geophysical Union. Geophys. Monogr. 63: 263-272.

Larios-Castillo SI. 2009. Evaluación del potencial de los recursos energéticos para su posible uso en la electrificación de Baja California. Ph.D. thesis, Universidad Autónoma de Baja California, Ensenada, Mexico (unpublished).

Lavín MF, Beier E, Badan A. 1997. Estructura hidrográfica y circulación del Golfo de California: Escalas estacional e interanual. Contribuciones a la Oceanografía Física en México, Unión Geofísica Mexicana, Monogr. No. 3: 141-171.

Markaki Z, Oikonomou K, Kocak M, Kouvarakis G, Chaniotaki A, Kubilay N, Mihalopoulos N. 2003. Atmospheric deposition of inorganic phosphorus in the Levantine Basin, eastern
Mediterranean: Spatial and temporal variability and its role in seawater productivity. Limnol. Oceanogr. 48: 1557-1568.

Martin JH. 1992. Iron as limiting factor in oceanic productivity. In: Falkowski PG, Woodhead AD (eds.), Primary Productivity and Biogeochemical Cycles in the Sea. Plenum, pp. 123-137.

Martin JH, Gordon RM. 1988. Northeast Pacific iron distributions in relation to phytoplankton productivity. Deep-Sea Res. 35: 177-196.

Martin JH, Gordon RM, Fitzwater SE, Broenkow WW. 1989. VERTEX: Phytoplankton/iron studies in the Gulf of Alaska. Deep-Sea Res. 36: 649-680.

Measures C, Vink S. 2001. Dissolved Fe in the upper waters of the Pacific sector of the Southern Ocean. Deep-Sea Res. (Part I) 48: 3913-3941.

Moffett JW. 2001. Transformations among different forms of iron in the ocean. In:Turner DR, Hunter KA (eds.), The Biogeochemistry of Iron in Seawater. John Wiley, New York, pp. 344-372.

Moore JK, Braucher O. 2007. Observations of dissolved iron concentration in the world ocean: Implications and constraints for ocean biogeochemical models. Biogeosci. Discuss. 4: 1241-1277.

Parsons TR, Maita Y, Lalli CM. 1984. A Manual of Chemical and Biological Methods for Seawater Analysis. Pergamon Press, Oxford $173 \mathrm{pp}$.

Pulido-Villena E, Wagener T, Guieu C. 2008 Bacterial response to dust pulses in the western Mediterranean: Implications for carbon cycling in the oligotrophic ocean. Global Biogeochem. Cycles 22, GB1020, doi:10.1029/2007GB003091.

Santamaría-del Ángel E, Álvarez-Borrego S. 1994. Gulf of California biogeography regions based on coastal zone color scanner imagery. J. Geophys. Res. 99: 7411-7421.

Sarthou G, Jeandel C. 2001. Seasonal variations of iron concentrations in the Ligurian Sea and iron budget in the western Mediterranean Sea. Mar. Chem. 74: 115-129.

Schüßler U, Balzer W, Deeken A. 2005. Dissolved Al distribution, particulate Al fluxes and coupling to atmospheric Al and dust deposition in the Arabian Sea. Deep-Sea Res. (Part II) 52: $1862-1878$.

Segovia-Zavala JA, Delgadillo-Hinojosa F, Álvarez-Borrego S. 1998. Cadmium in the coastal upwelling area adjacent to the CaliforniaMexico border. Estuar. Coast. Shelf Sci. 46: 475-481.

Simpson JH, Hughes DG, Morris NCG. 1977. The relation of seasonal stratification to tidal mixing on the continental shelf. In: Angel M (ed.), A Voyage to Discovery. Deep-Sea Res. (Suppl.) pp. 327-340.

Soto-Mardones L, Marinone SG, Parés-Sierra A. 1999. Variabilidad espaciotemporal de la temperatura superficial del mar en el Golfo de California. Cienc. Mar. 25: 1-30.

Spokes LJ, Jickells TD. 1996. Factors controlling the solubility of aerosol trace metals in the atmosphere and on mixing into seawater. Aquat. Geochem. I: 355-374.

Thunell RC. 1998. Seasonal and annual variability in particle fluxes in the Gulf of California: A response to climate change. Deep-Sea Res. (Part I) 45: 2083-3059.

Turner RD, Hunter KA, de Baar HJW. 2001. The iron paradox. In: Turner DR, Hunter KA (eds.), The Biogeochemistry of Iron in Seawater. John Wiley, New York, pp. 1-7.

Williams GA, Turekian KK. 2002. Atmospheric supply of osmium to the oceans. Geochim. Cosmochim. Acta 66: 3789-3791.

Wu J, Boyle E, Sunda W, Wen L-S. 2001. Soluble and colloidal iron in the oligotrophic North Atlantic and North Pacific. Science 293: 847-849.

Recibido en mayo de 2008; aceptado en febrero de 2009. 